\title{
ISTORIJA
}

\section{LIETUVOS SOCIALDEMOKRATAI IR \\ STEIGIAMASIS SEIMAS: DALYVAVIMAS RINKIMUOSE, REZULTATAI, FRAKCIJA}

Dr. Gintaras Mitrulevičius

El.paštasmitrgint@gmail.com

\section{Santrauka}

Straipsnyje remiantis ivairiais šaltiniais ir istoriografija aptariama istorineje literatūroje kol kas pakankamo demesio nesulaukę tokie Lietuvos socialdemokraty partijos (LSDP) dalyvavimo Lietuvos Respublikos Steigiamojo Seimo rinkimuose aspektai kaip dalyvavimo rinkimuose aplinkybès ir ypatybès, kandidatų sąrašai, rinkimų rezultatai, ju vertinimas ir tomis aplinkybemis susiformavusi Steigiamojo Seimo Socialdemokratu frakcija.

Reikšminiai žodžiai: Steigiamasis Seimas; Seimo rinkimai (1920 m.); socialdemokratai (Lietuvos); LSDP; Socialdemokratų frakcija.

\section{Ivadas}

Anot lietuviškojo konstitucionalizmo istorikų, $1920 \mathrm{~m}$. balandžio 14-16 d. išrinktas Steigiamasis Seimas „buvo ne ịprasta parlamentinè institucija, bet institucija, specialiai išrinkta atkurtos valstybès teisiniams pagrindams nustatyti“" Kaip žinoma, Steigiamojo Seimo arba Konstitucinio Seimo, tarptautinèje terminijoje dar dažnai vadinamo

Maksimaitis, M. Lietuvos valstybès konstitucijų istorija. Vilnius, 2005, p. 92. 
Konstituanta (nuo prancūzų k. žodžio La Constituante), pagrindinis uždavinys yra parengti valstybès konstituciją ir ją priimti². Tai yra Steigiamasis Seimas parengia ir priima pagrindinị šalies įstatymą, kuriuo nustatoma valstybès valdymo forma, valdžios institucijų formavimo ir funkcionavimo tvarka bei formos, jų paskirtis, galios, kompetencijos, jų tarpusavio santykiai, taip pat valstybès piliečių turimos teisès, pareigos ir laisvès ${ }^{3}$. Tokie steigiamieji parlamentai - Konstituantos buvo šaukiami naujiems valstybès "pamatams pakloti“ faktiškai visose po Pirmojo pasaulinio karo susikūrusiose naujose ar anksčiau turètą valstybingumą naujai atkūrusiose valstybèse, kaip, beje, ir politinę santvarką pakeitusiose minėtų valstybių teritorijas valdžiusiose valstybėse ${ }^{4}$.

Taigi Lietuvos Steigiamasis Seimas turèjo, Mykolo Römerio žodžiais tariant, „tvirtai organizuoti įsteigtą Lietuvos valstybę ir jos valdžios, ir net jos pačios laikinąji pobūdi pakeisti tvirtu ir nuolatinès valstybès ir valdžios pobūdžiu, taip sakant ją ịteisinti ir stabilizuoti“" Arba, teisès istoriko Mindaugo Maksimaičio žodžiais tariant, „Steigiamasis Seimas, kaip speciali institucija reprezentuojanti steigiamąją Lietuvos tautos galią“ turèjo "galutinai nustatyti atkuriamos Lietuvos valstybès pamatus“6. Atsižvelgiant ị visa tai atsiranda natūralus Steigiamojo Seimo, kaip „vienos iš reikšmingiausių naujųjų laikų mūsų valstybès kūrimo bei ịtvirtinimo institucijų“, turèjusių „didelę reikšmę parlamentarizmo raidai“, vertinimas 7 . Tokia Steigiamojo Seimo

2 Kasperavičius, A. Steigiamasis Seimas ir jo oratoriai. Lietuvos istorijos studijos. Nr. 12, 2003, Vilnius, p. 37.

3 Čepėnas, P. Naujujų laiku Lietuvos istorija. T. 2, Chicago, 1986, p. 673.

4 Kasperavičius, A. Min. veik., p. 37; Truska, L. Steigiamasis Seimas ir jo vieta naujųjų laikų Lietuvos istorijoje. Lietuvos Steigiamojo Seimo (1920-1922 metu) nariu biografinis žodynas. Vilnius, 2006, p. 17.

5 Rèmeris, M. Lietuvos konstitucinès teisés paskaitos. Vilnius, 1990, p. 86.

6 Maksimaitis, M. Parlamentarizmo teisinis reguliavimas Lietuvoje 1918-1940 metais. Parlamentas ir valstybinès valdžios institucijų sąranga. Liber Amicorum Česlovui Juršénui. Vilnius, 2008, p. 42.

7 Šenavičius, A. Lietuvos parlamentarizmo tradicijos: Steigiamasis Seimas. Parlamentas ir valstybinès valdžios instituciju sąranga... p. 93. 
reikšmė natūraliai lemia istorikų poreikị tyrinèti įvairius šios institucijos genezès, rinkimų, jų rezultatų, darbo, politinès sudèties, politinių frakcijų tarpusavio santykių, priimtų sprendimų aspektus.

Šio straipsnio objektas yra toks su Steigiamuoju Seimu (toliau - St. Seimu), jo rinkimais bei jų rezultatais susijęs to meto Lietuvos politinès istorijos aspektas kaip Lietuvos socialdemokratų partijos dalyvavimas St. Seimo rinkimuose. Kaip žinoma, parlamento, kaip aukščiausios valdžios institucijos, idejja, nors tiesiogiai tai ir nebuvo paminèta, tačiau išplaukè iš $1896 \mathrm{~m}$. priimtos pirmosios LSDP programos politinių reikalavimų dalies, iš pirmų dviejų būsimos demokratinès respublikos „konstitucijos pamatų“ punktų, kuriuose buvo pasisakyta už visuotinio, slapto, lygaus ir tiesioginio balsavimo principą „prie visokių rinkimų“, už proporcinę rinkimų sistemą ir „žmonių renkamą valdžią"8.

1905 m. sausio mènesị išleistame LSDP atsišaukime manifeste jau randame ir konkrečiai suformuluotą parlamento - Seimo Vilniuje reikalavimą ${ }^{9}$, kuris tų pačių 1905 m. balandi LSDP laikraštyje „Darbininkų balsas“ jo redaktoriaus A. Janulaičio buvo transformuotas $\mathfrak{i}$ "Lietuvos İsteigiamojo Seimo“ reikalavimą ${ }^{10} .1905$ m. vasarą išleistame ir rudenị platintame garsiajame „Lietuvos socialdemokratų partijos manifeste“ jau visos LSDP vardu pasisakyta už „Lietuvos gyventojų visuotiniu, tiesiu, lygiu ir slaptu balsavimu, neskiriant tautos, tikejjimo ir lyties" išrinkto İsteigiamojo Seimo Vilniuje sušaukimą. Taip pat buvo pateikta detali minètam Seimui priimti reikalingų sprendimų ir veiksmų programa, susidedanti net iš 28 punktų ${ }^{11}$.

Pralaiméjus revoliucijai, partijos viduje laimejus „autonomistų srovei“ ir LSDP pradèjus pasisakyti už Lietuvos autonomiją Rusijos

8 Programas lietuviškos socialdemokratiškos partijos. Tilžè, 1896, p. 9.

9 [Janulaitis, A. ] Lietuvmečiai. Darbininku balsas. 1905, Nr. 2, p. 43.

${ }^{10}$ [Janulaitis, A. ] Isteigiamasis Rusijos Seimas ir Lietuvos Seimas. Darbininkų balsas. 1905, Nr. 4, p. 108.

11 Žr.: Priedas Nr. 2. Lietuvos socialdemokratu partijos manifestas, Kairys, S. Tau, Lietuva. Boston. 1964, p. 333-338. 
sudètyje, ši autonomija, socialdemokratų supratimu, privalejo turèti Seimą Vilniuje. Pirmojo pasaulinio karo metais LSDP iškèlus nepriklausomos demokratinès respublikos reikalavimą, ji platinančiuose nelegaliuose socialdemokratų atsišaukimuose buvo aiškinama, kad „Lietuvos reikalai turi būti valdomi demokratiškai išrinkto Seimo Vilniuje“ ir kad "laisva demokratinė Lietuva bus tvarkoma savo žmonių išrinkto Seimo ir jo valdomos valdžios"12.

1917 m. Lietuvoje veikę lietuvių socialdemokratai vèl aiškiai pasisakė už tai, kad būsimos Lietuvos valstybès vidaus politinę santvarką ir jos santykius su kaimynais tegali nustatyti St. Seimas, demokratiškai išrinktas visų Lietuvos piliečių. Tokios principinės pozicijos laikèsi ir Lietuvos Taryboje dirbę socialdemokratai S. Kairys ir M. Biržiška. Ypač tai jie pabrèžè $1918 \mathrm{~m}$. liepos mènesí, kai, protestuodami prieš Lietuvos Tarybos sprendimus paskelbti Lietuvą monarchija ir išrinkti karaliumi Wilhelmą von Urachą, traktuodami šiuos Lietuvos Tarybos (tuo metu jau pasivadinusios Lietuvos Valstybės Taryba - LVT) nutarimus kaip Lietuvių konferencijos politinès rezoliucijos dèl Lietuvos ateities bei Vasario 16-osios akto pažeidimus ir kaip St. Seimo galių uzurpavimą, pasitraukè iš LVT darbo ${ }^{13}$.

Tiek vèliau 1918 m., tiek 1919 m. socialdemokratai (tie, kurie po 1918 m. pabaigos - 1919 m. pradžios LSDP krizės liko ištikimi LSDP ir europinès socialdemokratijos ideologinei tradicijai) nuolat reikalavo kiek galima greičiau organizuoti St. Seimo rinkimus ${ }^{14}$. Deja, iš pradžių dẻl Vokietijos okupacinio režimo, vèliau dẻl prasidejjusių kovų su bolševikais, lenkais ir bermontininkais už Lietuvos valstybès nepriklausomybę nebuvo galimybès suorganizuoti St. Seimo rinkimų nei 1918 m. antroje pusejje, nei beveik per visus 1919 metus. St. Seimo

12 Mitrulevičius, G. Lietuvos socialdemokratijos ideologinè-politine raida 1914-1919 metais. Istoriografija, tarptautinis ir istorinis kontekstai, santykis su Lietuvos valstybingumo kürimu. Vilnius, 2017, p. 257-258, 286-287.

13 Apie socialdemokratų nuoseklų pasisakymą už St. Seimą 1917-1918 m. žr.: ten pat, p. $318,320,323,326,356-357,364-365,367-368,370-371,381-382,384,386$.

14 Ten pat, p. 563-564, 566, 568-572, 574, 588 etc... 
rinkimų įstatymas buvo LVT priimtas tik 1919 m. spalio 30 dieną. „Vyriausybès žiniose“ jis buvo paskelbtas gruodžio $2 \mathrm{~d}$., o valstybès Prezidentas A. Smetona rinkimų datą (1920 m. balandžio 14 ir 15 d.) paskyrè $1920 \mathrm{~m}$. sausio 12 dieną $^{15}$.

Taigi, kaip matome, Lietuvos socialdemokratai XX a. pradžioje ir ypač Pirmojo pasaulinio karo metais nuolatos ir nuosekliai kèle St. Seimo sušaukimo idejją. Šiame straipsnyje nagrinèjama, kaip socialdemokratams sekèsi dalyvauti jų ilgai siekto St. Seimo rinkimuose.

Straipsnio tikslas - remiantis įvairiais istorijos šaltiniais ir istoriografija, aptarti ir išanalizuoti tokius aspektus kaip Lietuvos socialdemokratų dalyvavimo St. Seimo rinkimuose aplinkybės ir ypatybès, kandidatų sąrašai, gauti rezultatai, jų vertinimas ir tomis sąlygomis susiformavusios Socialdemokratų frakcijos sudètis. Kad būtų igyvendintas šis tikslas, straipsniui keliami tokie uždaviniai:

1) išsiaiškinti socialdemokratų dalyvavimo St. Seimo rinkimų kampanijoje aplinkybes ir ypatybes;

2) įvairiais aspektais apibūdinti St. Seimo rinkimuose dalyvavusių LSDP narių sąrašus ir kandidatus;

3) aptarti St. Seimo rinkimuose socialdemokratų gautus rezultatus parodant ir apibūdinant juos tiek apibendrintu visos rinkimuose dalyvavusios Lietuvos teritorijos aspektu, tiek ir atskirų apskričių bei atskirų rinkimų apygardų aspektu;

4) parodyti, kaip patys to meto lietuvių socialdemokratai vertino St. Seimo rinkimus ir jų rezultatus (tai yra naudinga norint geriau pažinti ir suprasti autentiškas to meto socialdemokratų ideologinespolitines nuostatas);

5) įvairiais aspektais apibūdinti į St. Seimą išrinktus socialdemokratų atstovus ir visą Socialdemokratų frakciją.

Reikia pabrěžti, kad straipsnyje nebus aptariama rinkimų i St. Seimą LSDP programa. Bendroji partijos programa ir bendrai ideo-

${ }^{15}$ Truska, L. Min. veik., p. 18. 
loginès-programinès nuostatos, kuriomis partija vadovavosi $1919 \mathrm{~m}$. rudeni - $1920 \mathrm{~m}$. pavasari, yra pristatyta straipsnio autoriaus monografijos, skirtos Lietuvos socialdemokratijos ideologinei-politinei raidai 1914-1919 m., paskutiniame skyriuje ${ }^{16}$. O kad būtų buvusi kokia nors speciali partijos rinkimų programa, tokių žinių rasti nepavyko. Kaip žinome ir kaip matysime iš straipsnio, socialdemokratų veikla St. Seimo rinkimų kampanijos metu susidūrẻ su valdžios vykdomais varžymais. Partijos laikraščio leidimas iki pat rinkimų buvo uždraustas. Pati partija, kaip pabrěžta ir straipsnyje, buvo ką tik pradejusi atsikurti. Matyt, visa tai ir lèmè, kad socialdemokratai neturèjo kokios nors specialios rinkimų programos.

Apibūdinant straipsnio problematikos tyrimų būklę reikia pasakyti, kad istoriografijoje yra šiek tiek apibendrintai (kartais labai glaustai ar tik fragmentiškai) rašyta ir beveik visais tais (bet ne visais) Lietuvos socialdemokratų dalyvavimo St. Seimo rinkimuose aspektais, kurių nagrinėjimas yra nurodytas šio straipsnio uždaviniuose ir kurių aptarimas apskritai yra šio straipsnio tikslas. Pavyzdžiui, apie tai glaustai ir apibendrintai rašoma šio straipsnio autoriaus tekste, skirtame socialdemokratų veiklai Lietuvos Respublikos Seimuose 1920-1927 metais aptarti ${ }^{17}$. Itin glaustai ir fragmentiškai apie kai kuriuos šio straipsnio problematikos aspektus užsimenama išeivijos lietuvių socialdemokrato J. Vilčinsko istorineje apybraižoje, skirtoje lietuviškosios socialdemokratijos raidai ${ }^{18}$, taip pat nedideliuose istorikių D. Blažytès-Baužienès ir V. Kašauskienès straipsniuose, parengtuose kaip konferencijų pranešimai ir

${ }_{16}$ Mitrulevičius, G. Lietuvos socialdemokratijos ideologiné-politine raida 1914-1919 metais, p. 725-733 (apie LSDP programą), p. 739-744, 749 (bendrai apie ideologines nuostatas), taip pat p. 716-724 (apie to meto Lietuvos politinès raidos vertinimus 1919 m. rudenị ,Socialdemokrate“).

${ }^{17}$ Mitrulevičius, G. Socialdemokratai Lietuvos Respublikos Seimuose 1920-1927. Socialdemokratai Lietuvos Respublikos Seimuose. Vilnius, 2006, p. 63-66.

18 Žr.: Vilčinskas, J. Lietuvos socialdemokratija kovoje dèl krašto nepriklausomybès. Istorine apžvalga. London, 1985, p. 125-126. 
skirtuose LSDP frakcijai St. Seime bei jos nuostatoms Konstitucijos prièmimo procese ${ }^{19}$.

Be to, atskiri šio straipsnio problematikos aspektai labai glaustai, apibendrintai arba fragmentiškai yra apibūdinti ar tik paminèti istorikų ir kitų autorių tekstuose arba tekstų fragmentuose, skirtuose įvairių Lietuvos partijų kartu paèmus dalyvavimui St. Seimo rinkimuose (S. Noreikienès, A. Jakubčionio straipsniai ${ }^{20}$ ), tekstuose, skirtuose St. Seimui apskritai (V. Daugirdaitès-Sruogienès, L. Truskos, A. Šenavičiaus tekstai ${ }^{21}$ ), ir tekstuose, skirtuose tarpukario Lietuvos istorijai ${ }^{22}$, Lietuvos Seimų istorijai ${ }^{23}$, lietuviškų partijų istorijai ${ }^{24}$, moderniojo Lietuvos valstybingumo sukūrimo istorijai ${ }^{25}$, taip pat ir ívairiuose itin bendro pobūdžio to meto Lietuvos istorijos apibūdinimuose.

Tačiau, apskritai paėmus, straipsnyje nagrinejjama problematika tiek visumos, tiek atskirų jos aspektų (straipsniui keliamų uždavinių) požiūriu tikrai nèra pakankamai ištyrinèta. Pavyzdžiui, istorikų dèmesio beveik nèra sulaukę tokie LSDP santykio su St. Seimo rin-

${ }_{19} \check{Z} r$ : Blažytè, D. Socialdemokratų frakcija Steigiamajame seime. Socialinè demokratija Lietuvoje: LSDP ištakos ir raida. Vilnius, 1996, p. 43; Kašauskienė, V. Socialdemokratų opozicija LKDP konstitucinėms nuostatoms Steigiamajame Seime. Lietuvos Respublikos Konstitucija penkeriu metu perspektyvoje. Konferencijos medžiaga. Vilnius, 1998, p. 89.

${ }^{20}$ Noreikienè, S. Buržuazinès partijos seimų rinkimuose buržuazinio parlamentinio režimo Lietuvoje metais (1920-1926). 1. Steigiamojo Seimo rinkimai, MADA. 1978. T. 1 (62), p. 89-101; Jakubčionis, A. Politinès partijos Steigiamojo Seimo rinkimuose. 1920-1922 metu parlamentine patirtis: sprendimu politika, tikslai, aplinkybès. Vilnius, 2000, p. 20.

${ }^{21}$ Daugirdaitè-Sruogienè, V. Lietuvos Steigiamasis Seimas. New York, 1975, p. 26-27, 41; Truska, L. Min. veik., p. 22, 24-26; Šenavičius, A. Min. veik., p. 98.

22 Žr.: Lietuvos istorija. X tomas. I dalis. Nepriklausomybe (1918-1940 m.). Vilnius, 2013, p. 466-473; Nepriklausomos Lietuvos istorija. Chicago, 1992, p. 31-41; Klases ir politines partijos. Vilnius, 1978, p. 129-131.

${ }^{23}$ Blažytè-Baužienè, D; Tamošaitis, M; Truska, L. Lietuvos Seimo istorija XX-XXI a. pradžioje. Vilnius, 2009, p. 49, 51, 53.

${ }^{24}$ Bložè, M. Politinių partijų susikūrimas ir jų veikla Nepriklausomoje Lietuvoje. Lietuvos partijos bei partine sistema. T. 1. Kaunas, 1997, p. 57.

${ }^{25}$ Čepènas, P. Min. veik., p. 676, 679. 
kimais ir jų rezultatais aspektai kaip rinkimuose dalyvavusių socialdemokratų kandidatų sąrašų ir pačių kandidatų apibūdinimas, kaip patys socialdemokratai vertino savo dalyvavimą St. Seimo rinkimuose ir apskritai šiuos rinkimus bei jų rezultatus.

Galima teigti, kad, išskyrus bendrus lakoniškus rinkimų rezultatų visos Lietuvos mastu apibendrinimus, dėmesio nèra sulaukęs ir socialdemokratų gautų rezultatų St. Seimo rinkimuose aptarimas, išskyrus daugiau ar mažiau glaustus, viena vertus, vèlgi apibendrintus, o kita vertus, fragmentiškus apibūdinimus, ir lietuvių socialdemokratų dalyvavimo St. Seimo rinkimų kampanijoje aplinkybių bei ypatybių aptarimas $^{26}$. Nors apie socialdemokratus, išrinktus ị St. Seimą, ir jų sudarytą frakciją ịvairiais aspektais istoriografijoje ir yra šiek tiek rašyta $^{27}$, tačiau ir šis straipsnyje nagrinejjamas aspektas taip pat dar reikalauja išsamesnio aptarimo.

Žodžiu, galima teigti, kad tai, jog šiame straipsnyje nagrinejjami Lietuvos socialdemokratų santykio su St. Seimu klausimai iki šiol nèra deramai ištyrinèti ir aptarti istorinejje literatūroje, ir yra vienas iš motyvų (šalia savotiško proginio motyvo - $2020 \mathrm{~m}$. minèsime St. Seimo išrinkimo ir darbo pradžios šimtmetị), lèmusių šio straipsnio temos, objekto ir tikslo pasirinkimą.

Rengiant straipsnị buvo remtasi įvairiais istorijos šaltiniais (spauda, publikuoti ir archyviniai dokumentai, atsiminimai), istorikų tekstais, taikyti istorinis, lyginamasis, analizès ir sintezès metodai.

${ }_{26}$ Žr.: Noreikienè, S. Min. veik., p. 96-100; Mitrulevičius, G. Socialdemokratai Lietuvos Respublikos Seimuose 1920-1927, p. 65-68; Vilčinskas, J. Min. veik., p. $130-132$.

27 Žr.: Pakalka, J. Steigiamojo Seimo Lietuvos socialdemokratų (LSDP) frakcija. Mintis. Politikos ir kultūros žurnalas. London. 1971, p. 68-84; Daugirdaitè-Sruogienė, V. Min. veik., p. 41, 43, 47; Vilčinskas, J. Min. veik., p. 125-126; Blažytė, D. Min. veik., p. 43; Kašauskienė, V. Min. veik., p. 89; Mitrulevičius, G. Socialdemokratai Lietuvos Respublikos Seimuose 1920-1927, p. 65-66; Truska, L. Min. veik., p. 26. 


\section{Lietuvos socialdemokratų dalyvavimo St. Seimo rinkimų kam-} panijoje aplinkybès ir ypatybès

Prieš pradedant konkrečiai kalbèti apie socialdemokratų dalyvavimą St. Seimo rinkimų kampanijoje pirmiausia reiktų (tam, kad būtų su kuo palyginti socialdemokratų dalyvavimą) glaustai apibūdinti pagrindines šioje rinkimų kampanijoje dalyvavusias politines jègas.

Taigi, nors St. Seimo rinkimuose dalyvavo net 31-as partijų, organizacijų ir nepartinių „susigrupavimų“ sąrašas, tačiau pagrindinè kova rinkimų kampanijoje, kaip žinoma, vyko tarp ịtakingiausių tuo metu lietuvių politinių jègų: iš vienos pusès - Krikščionių demokratų bloko, j̇ kurị ịejo Lietuvos krikščionių demokratų partija (LKDP), Lietuvos ūkininkų sąjunga (LŪS) ir Lietuvos darbo federacija (LDF), iš kitos pusès - Lietuvos socialistų liaudininkų demokratų partijos (LSLDP) ir Lietuvos valstiečių sąjungos (LVS) bloko ${ }^{28}$.

Lietuvos krikščionių demokratų partija (LKDP) aktyviai rengtis St. Seimo rinkimams pradejo jau nuo 1919 m. rugpjūčio mėnesį vykusios konferencijos. Jau tuo metu 50 skyrių ir apie 9000 narių turejusi LKDP, intensyviai rengdamasi rinkimams, stengèsi plèsti savo ịtaką tiek tarp darbininkų, tiek tarp ūkininkų. Tuo tikslu 1919 m. rugsèji ir gruodị buvo įkurtos su LKDP glaudžiai susijusios, LKDP atžvilgiu labai artimos minètos LDF ir LŪS. Pirmoji, ką tik susikūrusi, jos pačios duomenimis, turèjo 5000 narių $^{29} .1920$ m. pradžioje pati LKDP

28 Žr.: Seimo rinkimai, Lietuvos statistikos metraštis. T. 1, 1924-1926. Kaunas, 1927, p. 72-73; Daugirdaitè-Sruogienè, V. Min. veik., p. 25-36; Noreikienè, S. Min. veik., p. 89-101; Čepėnas, P. Min. veik., p. 677-79; Jakštas, J. Min. veik., p. 31-41; Truska, L. Min. veik., p. 20-24; Blažytė-Baužienė, D.; Tamošaitis, M.; Truska, L. Min. veik., p. $46-50$.

29 Žr.: Noreikienè, S. Min. veik., p. 93-94; Čepėnas, P. Min. veik., p. 677; Truska, L. Min. veik., p. 22-23; Jakubčionis, A. Min. veik., p. 18. Plačiau žr.: Bučelis, D. Lietuvių krikščionių demokratų partijos sukūrimas ir jos raida 1917-1920 m., Lietuviu kataliku mokslu akademijos metraštis X. Vilnius: Katalikų akademija, 1996, p. 551, 556-559; Svarauskas, A. Krikščioniškoji demokratija nepriklausomoje Lietuvoje (1918-1940). Politiné galia ir jos ribos. Vilnius, 2014, p. 77-79, 89-90, 95 etc... 
turejo net 58 skyrius. Socialdemokratai, kaip matysime, tuo metu iš viso neturejo savo spaudos, o Krikščionių demokratų blokas leido net ne vieną, o ištisą virtinę spaudos leidinių: „Laisvę“, „Ūkininką“, „Darbininką“, „Vienybę“30. Istoriografijoje nurodoma, kad 1919-1920 m. LKDP, neišsamiais duomenimis, išleido 25 nedidelès apimties knygeles politinemis temomis, daugelyje jų buvo siekiama „pakirsti konkuruojančių politinių partijų ịtaką “31.

Savo agitacijoje per St. Seimo rinkimų kampaniją krikščionys demokratai mokejjo prisitaikyti prie ịvairių socialinių sluoksnių, programoje daug dėmesio skyrè žemės, darbininkų klausimams ir net, istorikès S. Noreikienės žodžiais tariant, „negailejjo aštrių žodžių išnaudotojų klasių - dvarininkų ir buržuazijos - adresu“, „nevengè deklaracijų prieš kapitalistinę santvarką"32.

Istorikų yra pažymimas ir toks katalikiškame valstietiškame krašte palankus krikščionims demokratams veiksnys kaip kad Bažnyčios ir jos vadovybès dalyvavimas politinèje agitacijoje ${ }^{33}$.

St. Seimo rinkimuose pagrindinis Krikščionių demokratų bloko konkurentas buvo tuo metu opozicijoje esantis Valstiečių liaudininkų blokas, kurị sudarė LSLDP ir LVS. Šis blokas, nors neturèjo įtakingos Lietuvoje Katalikų Bažnyčios paramos ir tokių materialinių galimybių kaip Krikščionių demokratų blokas ir taip pat susidūrè su tam tikrais valdžios vykdomais jų politinès raiškos varžymais ${ }^{34}$, tačiau pasižymėjo tuo, kad viena iš bloko sudedamųjų dalių - LVS - buvo masinė organizacija. Jau 1919 m. balandžio 26-27 d. vykusiame LVS suvažiavime, anot LVS laikraščio „Lietuvos ūkininkas“, dalyvavę delegatai atstovavo keturiolikai LVS kuopų, kuriose buvo 758 nariai. 1919 m. rugsèjo 21 d. LVS centro komitete vykusiame posèdyje buvo

${ }^{30}$ Noreikienè, S. Min. veik., p. 93; Jakubčionis, A. Min. veik., p. 18.

${ }^{31}$ Noreikienè, S. Min. veik., p. 93.

32 Svarauskas, A. Min. veik., p. 80; Noreikienè, S. Min. veik., p. 94.

${ }^{33}$ Noreikienè, S. Min. veik., p. 93; Jakštas, J. Min. veik., p. 35; Truska, L. Min. veik., p. 22-23.

34 Noreikienè, S. Min. veik., p. 95. 
nurodyta, kad LVS tuo metu turejo apie 50 kuopų, kurios telkè kelis tūkstančius narių ${ }^{35}$.

LVS labai aiškiai identifikavosi su šalies gyventojų dauguma, ir ne tik pavadinimu. Be to, būdama organizaciniu požiūriu stipresniąja Valstiečių liaudininkų bloko organizacija, ji ideologiškai ir programiškai buvo veikiama bloko kairesnès partnerès LSLDP, kuri buvo savotiška ideologinè LSDP konkurentè. Mat LSLDP tuo metu dalyvavo atkurto II Internacionalo veikloje ${ }^{36}$ ir laike save, kaip buvo rašoma 1920 m. jų laikraštyje „Darbas“, „,vienintele Lietuvos socialistų organizacija, priklausančia socialistų Internacionalui“ ir „vienintele partija, kuri stovėdama ant tarptautinio socializmo pagrindų nè valandèlès neatsitolino nuo demokratijos idealų bei jos dèsnių ir visuomet, gindama darbo žmonių reikalavimus, gynè, gina ir gins lietuvių tautos teises ${ }^{\text {"37 }}$.

Taigi vienydamas savyje daug narių turinčią LVS ir bloke ideologiškai dominavusią LSLDP, turẻdamas spaudą ir tokių ryškių lyderių kaip M. Sleževičius ir K. Grinius, Valstiečių liaudininkų blokas buvo rimtas konkurentas socialdemokratams kovoje dèl rinkejų, kurie potencialiai galejo nepalaikyti dešiniųjų partijų, balsų. Nors pats šis rinkimų blokas, kaip liudija žvilgsnis i jị sudarančių politinių jègų laikraščius „Darbas“ ir „Lietuvos ūkininkas“, savo rinkimų kampaniją grindè oponavimu ne, kaip matysime, tuo metu palyginti silpniems, í sudétingą padèti patekusiems ir darbininkų klasei pretenduojantiems atstovauti socialdemokratams, o oponavimu krikščionims demokratams ir kova su jais dèl šalies gyventojų daugumą sudariusių valstiečių balsų.

Apibūdinę pagrindines St. Seimo rinkimų kampanijoje konkuravusias politines jègas, pereikime prie pagrindinio šio skyrelio

${ }^{35}$ Stakeliūnaitè, D. Valstiečiai liaudininkai Lietuvos Respublikos vidaus politikoje 1918 m. pabaigoje - 1926 m.: parlamentinè veikla. Daktaro disertacija. Kaunas, 2000, p. 34-35.

${ }^{36}$ Žr., pvz.: A. R. Iš Internacionalo darbuotès. Darbas. 192004 04, Nr. 25, p. 2.

${ }^{37}$ Gegužès 1 d. Darbas. 192005 01, Nr. 32, p. 1. 
klausimo, tai yra klausimo, kokios buvo LSDP veiklos galimybès ir aplinkybès prasidejus St. Seimo rinkimų kampanijai.

Taigi, reikia konstatuoti, kad LSDP partinès organizacinès struktūros plètros ir narių skaičiaus aspektais buvo nepalyginamai silpnesnė partija negu kad ị Krikščionių demokratų ir Valstiečių liaudininkų blokus ịejusios partijos, visų pirma, lyginant su LKDP ir LVS. Kaip žinoma, 1917 m. - 1919 m. pradžioje lietuviškoji socialdemokratija (kaip ir nemažo skaičiaus kitų šalių socialdemokratinių judejjimų) patyrè keletą rusiškojo bolševizmo poveikio bangų. Dėl to nuo jos atsiskyrè ir komunistais virto mažesnès ar didesnès lietuvių socialdemokratų grupès, paveiktos šio proceso ir patyrusios probolševikinęprokomunistinę evoliuciją ${ }^{38}$.

Paskutinè iš minėtų bolševizmo poveikio bangų pasireiške $1918 \mathrm{~m}$. pabaigoje - 1919 m. pradžioje LSDP idejjine-politine bei organizacine krize ir susiskaldymu, taip pat ir tuo, kad viena iš LSDP srovių (beje, viešai besireiškusi visos partijos vardu) 1919 m. sausio pabaigoje - vasario mėnesi paskelbè, jog LSDP pasivadina Lietuvos komunistų partija (vadinamoji A. Domaševičiaus LKP). Po jos išreikšto, bet neįvykusio siekio susijungti su LBKP ir dèl to, kad lenkams užėmus Vilnių ši grupė visiškai pakriko, lietuviškajam socialdemokratiniam judejjimui ir LSDP 1919 m. toliau teatstovavo tik nedidelè grupele socialdemokratų su J. Pakniu ir S. Kairiu priešakyje, įejjusiais ị M. Sleževičiaus vadovaujamas Lietuvos laikinąsias vyriausybes, kovojusias su bolševikais ${ }^{39}$.

Ši grupele 1919 m. rudenị, esant beveik visiškam LSDP organizaciniam suirimui, jai priklausantiems asmenims patiriant aršų nelegaliai veikusių komunistų puolimą, o nuo spalio mėnesio ir tam tikrus val-

${ }^{38}$ Glaustai apie tai žr.: Mitrulevičius, G. Lietuvos socialdemokratai iki Steigiamojo Seimo, Socialdemokratai Lietuvos Respublikos Seimuose. Vilnius, 2006, p. 53-59. Plačiau žr.: Mitrulevičius, G. Lietuvos socialdemokratijos ideologinè-politinè raida 1914-1919 metais... p. 388-548, 614-693.

39 Ten pat, [atitinkamai] p. 59-60 ir p. 614-693. 
džios trukdymus, pradejo partijos organizacinio ir politinio veikimo atkūrimo procesą. Kaip 1925 m. LSDP XII suvažiavime, apibūdindamas partijos organizacinę raidą nuo 1919 m. iki 1925 m., tvirtino vienas iš partijos lyderių K. Bielinis, $1919 \mathrm{~m}$. antroje pusèje - $1920 \mathrm{~m}$. pirmoje puseje LSDP tebuvo tik „būrelis draugų“40.

Taigi turèdami mintyje 1918 m. pabaigos - 1919 m. pradžios LSDP idejjinès-politinès ir organizacinès krizès pasekmes partijai ir kokia buvo partijos organizacinè būklè St. Seimo rinkimų kampanijos metu, matyt, iš tiesų galime pritarti istoriografijoje išsakytoms mintims, kad LSDP per St. Seimo rinkimų kampaniją „išgyveno kūrimosi stadiją “41. Be jokios abejonės, tokios aplinkybės traktuotinos kaip itin nepalankus veiksnys partijos sėkmingam dalyvavimui St. Seimo rinkimuose.

Sẻkmingam LSDP dalyvavimui nebuvo palankūs ir tokie veiksniai kaip nedidelis šalies industrializavimo ir urbanizacijos laipsnis, agrarinis, valstietiškas krašto pobūdis, didelis gyvenančių kaime ir dirbančių žemės ūkyje skaičius ir menkas pramonès darbininkų skaičius. Kaip žinoma, 1923 m. vykusio visuotinio Lietuvos gyventojų surašymo duomenimis, paaiškejjo, kad Lietuvoje (be Lietuvos Respublikai tuo metu nepriklausiusio Vilniaus krašto ir be Klaipeddos krašto) 84,2 proc. gyventojų gyveno kaime (miestu buvo laikoma gyvenvieté, turinti bent 2000 gyventojų), o žemès ūkyje dirbo 76,7 procento ${ }^{42}$. Pramoneje dirbo tik 6,4 proc. (susisiekimo ir ryšių sistemoje - 1,1 proc., prekyboje $-2,5$ proc., valstybès ir visuomeninèse įstaigose $-3,2$ proc., kituose sektoriuose - 10,1 proc.) Lietuvos gyventojų ${ }^{43}$.

Taigi Lietuva buvo valstietiškas, tai yra žemès ūkio, kraštas. O socialdemokratinio judejjimo socialinis pagrindas (socialinè bazè)

40 Žr.: Partijos organizacinès darbuotès apžvalga 1924-1925 metais, LCVA, f. 937, ap. 1, b. 34, 1. 29.

${ }^{41}$ Truska, L. Min. veik., p. 22.

${ }^{42}$ Klasés ir politinés partijos Lietuvoje 1919-1926 m., p. 12.

${ }^{43}$ Ten pat. 
XIX a. pabaigoje - XX a. pirmoje pusėje, kaip kad gerai yra žinoma, buvo darbininkija. Tačiau ir dèl šios negausios darbininkijos (ypač dèl kaimo darbininkijos) interesų išreiškimo ir atstovavimo socialdemokratams teko varžytis ne tik su komunistais, ị kurių puolimą socialdemokratų atžvilgiu netrukus atkreipsime dèmesị, bet ir su LDF, kuri 1919 m. pabaigoje - 1920 m. pradžioje kaip organizacija buvo gerokai stipresnè už LSDP. Anot istoriko A. Svarausko, pradedant St. Seimu, LDF buvo panaudota kaip „katalikų politinès srovès atšaka, skirta igyti darbininkų balsų “44.

Taigi, to meto Lietuvos socialinio ir ekonominio išsivystymo būklè bei socialinè struktūra nesudarè prielaidų LSDP sėkmingai dalyvauti St. Seimo rinkimuose. Su agrariniu-valstietišku-kaimišku krašto pobūdžiu buvo susiję ir kiti sèkmingam socialdemokratų dalyvavimui St. Seimo rinkimuose nepalankūs veiksniai kaip didelè Katalikų Bažnyčios įtaka Lietuvoje ir katalikiškai konservatyvus daugelio šalies gyventojų mentalitetas ${ }^{45}$.

Toliau apibūdinant LSDP dalyvavimo St. Seimo rinkimų kampanijoje aplinkybes, o ir apskritai jos to meto veiklos - raiškos ypatybes, reikètų pabrèžti, kad esant anksčiau ką tik minėtoms objektyvioms LSDP didelę ịtaką ígyti neleidžiančioms, nuo Lietuvos socialinio ir ekonominio išsivystymo priklausančioms aplinkybèms ir tuometinei LSDP organizacinei būklei, socialdemokratams nebuvo taip lengva veikti ir igyti įtaką ir tarp tų negausių miesto darbininkų, dèl kurių komunistai vedė aršią idèjinę-politinę kovą su jais.

Jau vien žvilgsnis ị tik beatsikuriančios LSDP ir atskirų jos veikẻjų „vertinimą“ - smarkų puolimą to meto komunistinèje spaudoje, jų vadinimą visokiausiais „social-pardavikais“, „social-išdavikais“, „social-parsidavėliais“, „darbininkų priešų tarnais“, „buožių agentais darbininkų eilèse “ ir panašiai ${ }^{46}$ - leidžia visiškai pritarti K. Bielinio

${ }^{44}$ Svarauskas A. Min. veik., p. 90 etc.

45 Žr., pvz.: Jakštas, J. Min. veik., p. 30-31.

46 Žr.: Bevardis, M. [Angarietis, Z.] Atsikelia iš numirusių. Komunistas, 191908 
1925 m. LSDP XII suvažiavime išsakytai minčiai, kad komunistai 1919 m. rudenị „kiekviename žingsnyje žemino“ LSDP vardą, „plūdo“ atskirus socialdemokratų veikejjus ir „žadino Lietuvos darbininkuose greito ir tikro laimėjimo Maskvos durtuvų pagalba" dvasią ${ }^{47}$.

LSDP organizacinị atsikūrimą ir veikimą, drauge ir dalyvavimą St. Seimo rinkimų kampanijoje sunkino ir tai, kad tuo metu, anot čia cituoto K. Bielinio pranešimo, ir „susikūrusiose profesinèse sąjungose, jų viršūnèse vyravo ir toji pat [komunistinè - G. M. pastaba] demagogija [socialdemokratų atžvilgiu - G. M. pastaba] ir darbininkų jègų skaldymas“48. Kaip vèliau savo atsiminimuose rašè K. Bielinis, „bolševikai pralaimėję Pabaltijo valstybių grąžinimo ị Rusiją bylą karo lauke, turimas ir tinkamas jẻgas perkèlè $\mathfrak{i}$ darbininkų profesinị sąjūdị, dẻdami daug pastangų paversti ši sąjūdị savo politinių siekimų įrankiu“49. Ir tai jiems tuo metu - 1919 m. rudenị, pasak cituojamo žymaus LSDP veikèjo, „sekèsi, nes smarkiai nusilpusi LSDP negalėjo profesiniam darbininkų sąjūdžiui skirti pakankamai žmonių ir lèšų “50.

24, Nr. 69, p. 2; Angarietis, Z. Lietuvos social-pardavikų pirmtakūnai, ten pat, p. 3; Kairys, Paknys, Sleževičius visi tarnauja darbininkų priešams, ten pat, Nr. 19, p. 4; Kapsukas, V. Vèl išlindo... L.S.-D.P, ten pat, 191909 05, Nr. 73, p. 2-3; B-is, M. [Angarietis, Z.] Social-pardavikų konferencija, ten pat, 191910 25, Nr. 75, p. 4; B-is, M. [Angarietis, Z.] Išlenda ylos iš maišo. 191910 30, Nr. 76, p. 2; Kaip perekinčikas Požela registravo bolševikus, ten pat, p. 5; Social-išdavikų balsas, ten pat, p. 5; Kaunietis. Social-pardavikų jègos, ten pat, 191911 07, Nr. 77, p. 3-4; Angarietis, Z. Ar galima eiti išvien su social-pardavikais? ten pat, p. 3-4; Korespondencijos, ten pat, 191911 17, Nr. 78, p. 7-8; V. K. Buožių agentai darbininkų eilèse, ten pat, 191911 15, Nr. 79, p. 3; LSDP - social-parsidavèliai, ten pat, 191911 30, Nr. 80, p. 20; V. G. [Kapsukas, V.] Nebuvėlė LSDP konferencija, ten pat, p. 22; A., Z. [Angarietis, Z.] Blogos lauko darbininkų padèties kaltininkai, ten pat, 191912 07, Nr. 81, p. 41; A., Z. [Angarietis, Z.] Visų tautų social-pardavikai vienodi, ten pat, 191912 31, Nr. 84 (116), p. 85.

47 Partijos organizacinès darbuotės apžvalga 1924-1925 metais, LCVA, f. 937, ap. 1, b. $34,1.30$.

48 Ten pat.

49 Bielinis, K. Gana to jungo. New York. 1971, p. 417.

50 Ten pat, p. 417-418. 
Taigi, vieno iš tuometinių LSDP lyderių K. Bielinio teigimu, socialdemokratams rinkimų i St. Seimą kampanijoje labai trukdè „bolševikų skaldomasis darbas“. Būtent jis, anot minèto socialdemokrato, daug „svèrë“ Marijampolès ir Telšių apygardose, dèl to „socialdemokratų partija čia nespejo atsistatyti ir neįteikè kandidatų sąrašų “51. Kalbant apie Marijampolès apskritị, neatmestina, kad čia socialdemokratų „neatsistatymui“ ịtaką darè šios apskrities socialistinèje politinejje spektro dalyje su jais konkuravę ir tam tikros reikšmės turèję, kurị laiką ir savo laikraštị „Žemè ir laisvè“ leidę revoliuciniai socialistai liaudininkai ${ }^{52}$. Reikia priminti, kad 1920 m. pradžioje socialdemokratams Lietuvoje dèl ịtakos darbininkijai ir socialistinèms idejoms paveikiai inteligentijai reikejjo konkuruoti ne tik su komunistais, bet ir su kitomis radikaliomis socialistinèmis grupèmis ${ }^{53}$.

Dar vienas nepalankus veiksnys sẻkmingam socialdemokratų dalyvavimui St. Seimo rinkimuose buvo tai, kad 1919 m. rudeni - 1920 m. pavasarị LSDP susidūrè su tam tikrais valdžios daromais jų veiklos varžymais. $1919 \mathrm{~m}$. spalio pabaigoje socialdemokratams nebuvo leista organizuoti savo partijos konferencijos ${ }^{54}$. 1919 m. lapkričio 30 d. prièmus spaudos įstatymą, jau netrukus - 1919 m. gruodžio $18 \mathrm{~d}$. buvo uždraustas Lietuvos socialdemokratų partijos laikraštis „Socialdemokratas“, 1919 m. teišèjus tik keturiolikai šio laikraščio numerių. O juk spauda tuo metu vaidino labai svarbų vaidmenị rinkimų agitacijoje.

"Socialdemokrato“ leidimas atnaujintas tik po St. Seimo rinkimų 1920 m. balandžio 17 dieną. Socialdemokratų veiklą dažnai varžè ir karo stovis, kuriam esant galiojo ypatingieji valstybės apsaugos įstatymai, suteikę plačius igaliojimus karo komendantams ir smarkiai

51 Partijos organizacinès darbuotès apžvalga 1924-1925 metais, LCVA, f. 937, ap. 1, b. $34,1.29$.

52 Žr.: Marijampolèje leistą Žemę ir laisvę, 1920. Taip pat Marijampolèje 1919-1920 m. buvo leidžiamas ir revoliuciniams socialistams liaudininkams artimas žurnalas ,Aušrine்“.

53 Žr., pvz.: Dèl agitacijos. Darbas. 192001 11, Nr. 2, p. 1.

54 Iš Partijos gyvenimo. Socialdemokratas. 191911 06; Nr. 8, p. 1. 
apriboję konstitucines piliečių laisves. Karo stovis buvo panaikintas tik 1920 m. kovo 1 d., kai iki kandidatų sąrašų sudarymo buvo likę tik pusantro ménesio ${ }^{55}$.

Reikia pabrèžti, kad tiek iki karo stovio panaikinimo, tiek ir vèliau pasitaikydavo, jog valdžia trumpam laikui sulaikydavo LSDP veikèjus, net pačius lyderius, darydavo kratas net jų pačių namuose ar skirdavo namų arešto. Pavyzdžiui, $1920 \mathrm{~m}$. vasario ménesį LSDP lyderis S. Kairys, apkaltintas tuo, kad jo skaityta paskaita „Lietuvių - lenkų santykiai ir Steigiamasis Seimas" virto mitingu, vieną parą buvo išlaikytas namų arešto sąlygomis Šiauliuose ${ }^{56}$.

1920 m. kovo 13 d. veždamas iš Šiaulių ị Panevėžio rinkimų apygardą LSDP rinkimų sąrašą, Radviliškio geležinkelio stotyje trumpam buvo sulaikytas Šiaulių apskrities valdybos ir Panevėžio rinkimų apygardos rinkimų komisijos narys, kandidatas i St. Seimo narius, vienas iš veikliausių beatsikuriančios LSDP veikèjų K. Bielinis ${ }^{57}$.

Kadangi, kaip savo atsiminimuose rašo K. Bielinis, tai buvo paskutinė rinkimų sąrašų ịteikimo apygardos komisijai diena, tai jis dèl šio sulaikymo rizikavo pavèluoti pateikti registracijai LSDP rinkimų sąrašą, dèl ko būtų prarasta galimybė LSDP dalyvauti St. Seimo rinkimuose minimoje rinkimų apygardoje ${ }^{58}$. Savo atsiminimuose K. Bielinis tvirtino, kad minètas jo sulaikymas nebuvo atsitiktinis ir kad tai buvo „kvalifikuotų politinių kriminalistų sumanymas“59.

Tačiau vienas iš $\mathrm{K}$. Bielinio suėmimą mačiusių žmonių skubiai telefonu paskambino Šiaulių apskrities valdybos pirmininkui socialdemokratui K. Venclauskiui. Šis paskambino ị Radviliškio komendantūrą, kur buvo nuvestas sulaikytas K. Bielinis, ir, „energingai“

${ }^{55}$ Truska, L. Min. veik., p. 20; Maksimaitis, M. Teisinis rengimasis Steigiamojo Seimo rinkimams, p. 117-118.

${ }^{56}$ Truska, L. Min. veik., p. 17; Kairys, S. Laiškas redakcijai. Darbas. 192002 17, Nr. 12, p. 2.

${ }^{57}$ Žr.: LCVA, f. 923, ap. 1, b. 94, 1. 16; Bielinis, K. Min. veik., p. 451-452.

${ }^{58}$ Bielinis, K. Min. veik., p. 451-452.

${ }^{59}$ Ten pat, p. 452. 
Šiaulių apskrities valdybos vardu užprotestavęs dèl šio sulaikymo, griežtai pareikalavo K. Bielinị tučtuojau paleisti. Tas netrukus ir buvo padaryta, tad K. Bielinis spejjo nuvažiuoti ị Panevèží, ị rinkimų komisijos posėdị ir užregistruoti LSDP sąrašą ${ }^{60}$.

Tačiau insinuacijos prieš socialdemokratus vyko ir toliau. Štai praejjus dienai po K. Bielinio suèmimo, naktị iš 1920 m. kovo 14 d. ị 15 d. buvo padarytos kratos pas pati minètąji Šiaulių apskrities valdybos pirmininką, socialdemokratą, kandidatą i St. Seimo narius K. Venclauskị ir pas kai kuriuos kitus Šiaulių apskrities socialdemokratus ${ }^{61}$.

Čia ką tik paminèti ịvykiai rodo tam tikrą politinị foną, kuriam esant Lietuvos socialdemokratai turejo veikti ir dalyvauti St. Seimo rinkimų kampanijoje. Šj foną turètų dar paryškinti ir patikima laikytina 1920 m. „Socialdemokrate“ pateikta informacija apie tai, kad St. Seimo rinkimų kampanijos metu rinkimų mitinguose socialdemokratams, anot minimo laikraščio korespondento, „keldamos didžiausią triukšmą kliude kalbèti krikščionių demokratų partijos davatkos $^{\text {“62 }}$. „Socialdemokrate“ buvo pranešta ir apie tai, kad viename iš rinkimų mitingų krikščionių demokratų „buvo kurstoma mušti LSDP atstovą V. Poželą“63.

Tenka iš dalies sutikti su istorinès apybraižos apie Lietuvos socialdemokratiją autoriumi J. Vilčinsku, pasak kurio, „mažai socialdemokratų partijai“ rinkimų i St. Seimą kampanijos metu „buvo sunku veikti“ ir kad „pilną veikimo laisvę prieš Steigiamojo Seimo sušaukimą turèjęs tik krikščionių demokratų blokas [Tautos pažangos partija turejo visišką laisvę, tačiau buvo silpna partijos organizacija - G. M. pastaba] dejo visas pastangas, kad socialdemokratai negalètų né pajudèti“. Nors tai yra socialdemokrato, taigi šališkas, požiūris, matyt, tam tikru laipsniu galime pritarti J. Vilčinsko teiginiui, kad krikščio-

${ }^{60}$ Ten pat, p. 451-452; LCVA, f. 923, ap. 1, b. 94, 1. 16.

${ }^{61}$ LCVA, f. 923, ap. 1, b. 94, 1. 16.

${ }^{62}$ Mūsų žinios. Socialdemokratas. 192005 06, Nr. 4 (118), p. 4.

${ }^{6}$ Ten pat. 
nys demokratai rinkimų kampanijoje „naudodami bolševizmo baubą $<\ldots>$ baugino visuomenę, <...> kad socialdemokratai ir bolševikai tai tas pats“, kad jie „norị Lietuvos nepriklausomybę sužlugdyti“64.

Jau po rinkimų - $1920 \mathrm{~m}$. balandžio $24 \mathrm{~d}$. „Socialdemokrato“ vedamajame straipsnyje „Dèl rinkimų i Seimą“ buvo aiškinama, kad per rinkimų kampaniją „krikščionims ne tik buvo suteikta „pilna laisvė, bet dar buvo teikiama komendantų ir milicijos pagalba"65. Straipsnyje nurodoma, kad per rinkimų kampaniją „kunigai pavertẻ bažnyčias mitingų salèmis, kur niekieno neprieštaraujami galëjo piršti „krikščionis" ir plūsti savo priešus“.

Pasak cituojamo straipsnio, kunigai ,išnaudojo išpažintị ir per ją veikè žmones balsuot už savo partiją“. Taip pat buvo rašoma, kad „per kunigus ant socialistų galvų buvo verčiami perkūnai ir išliejamos pamazgos ir buvo žadamas pragaras ir amžinas prakeiksmas tiems, kas nebalsuos už krikščionis“. „Žodžiu, - kaip rašė minimas „Socialdemokrato" vedamasis, - iš bažnyčios ir tikejjimo klerikalai pasidarè savo partijos kromelị, iš šventųjų savo patronus ir padejejejus, šlykščiai pasinaudodami žmonių pasitikejjimu, kaip dvasiški žmonių vadovai.“

Anot socialdemokratų, „klerikalai savo veikime nevengè melo, šmeižto ir darè neišpildomų pažadų“, „melagingai žmonėms ịkalbinejjo, kad socialistai išgriaus bažnyčias, panaikins tikejjimą ir „sakramentus“, atims iš ūkininkų žemes, tuojaus įves komunas ir t. t.“. „Socialdemokrate“ buvo teigiama, kad krikščionys demokratai „muša žmones lazdomis ne per galvas ir nugaras, bet skaudžia jų sielą, jų tikejjimo jausmus, be atodairos vartodami Kristaus ir Dievo vardą savo klasès reikalams apginti“. Taigi, anot socialdemokratų, jie [krikščionys demokratai - G. M. pastaba] yra „tikri spekuliantai“ ${ }^{66}$.

St. Seimo rinkimų kampanijai apibūdinti buvo skirtas ir $1920 \mathrm{~m}$. gegužès 13 d. „Socialdemokrate“išspausdintas „Raudonojo dobilèlio“pseu-

\footnotetext{
${ }^{64}$ Vilčinskas, J. Min. veik., p. 121.

65 Dèl rinkimų i Seimą. Socialdemokratas. 192004 24, Nr. 2 (16), p. 1.

66 Ten pat.
} 
donimu pasirašytas straipsnis „Krikščionių demokratų laimejjimas“67. Šiame straipsnyje buvo aiškinama, kad rinkimų i St. Seimą kampanijos metu „visi kairieji, ypač socialdemokratai, buvo ịtariami esą „bolševikai“ ir areštuojami“. Pasak straipsnio autoriaus, darbininkams buvo trukdoma organizuotis, jų profesinès sąjungos nebuvo registruojamos, o socialdemokratai prisiartinus rinkimams buvo suvaržyti, priversti tylèti. „Pilniausia laisve““, - kaip toliau rašoma straipsnyje, - buvo duota „tik krikščionių demokratų organizacijoms ir jų agitatoriams“. Taigi, straipsnio autoriaus teigimu, „kunigai bažnyčių sakyklas“, o kai kur „net klausyklas“ pavertė „politikos agitacijos tribūnomis“ ir „grasino nepriimsią išpažinties, nevažiuosią prie ligonių, baidè pragaru, jei kas išdrịs balsuoti ne už krikščionių demokratų „numerius “68

Socialdemokratai St. Seimo rinkimuose laikèsi nuostatos, kad vien tik jie „gali nuosaikiai [reikètų suprasti - nuosekliai - G. M. pasta$b a]$ ginti darbininkų mažažemių ir bežemių reikalus"69. Krikščionis demokratus jie apibūdindavo kaipo „užsislèpusius monarchininkus, žmonių valdžios ir darbininkų priešus, kaipo Dievo vardo spekuliantus“, kurie „savo partijos reikalams nesidrovi išnaudoti bažnyčios, išpažinties ir tikybinių žmogaus jausmų“. Būtent taip per rinkimų í St. Seimą kampaniją Utenos apskrityje krikščionis demokratus apibūdino LSDP lyderis S. Kairys ${ }^{70}$.

Nors, žinoma, visi čia minèti to meto socialdemokratų spaudoje pateikti St. Seimo rinkimų kampanijos vertinimai buvo veikiami aršios politinès kovos atmosferos ir, savaime suprantama, turejo tam tikrą politinị-ideologinị ir partinį tendencingumą, tačiau akivaizdu, kad turint mintyje to meto lietuviškosios politinès kultūros brandos (tiksliau - nebrandos) laipsnị, taip pat ir visuomenès raidos lygị, labai

${ }^{67}$ Raudonasis dobilèlis. Krikščionių demokratų laimèjimas. Socialdemokratas. 192005 13, Nr. 5 (19), p. 2-3.

68 Ten pat.

${ }^{69}$ Mūsų žinios. Socialdemokratas. 192004 24, Nr. 2 (16), p. 3.

70 Ten pat. 
tikètina, kad čia minèti St. Seimo rinkimų kampanijos dalykai, apibūdinti ne faktų pateikimo, o komentaro - interpretacijos pateikimo būdu, tam tikru laipsniu iš tikrųjų reiškèsi.

Baigdami apibūdinti socialdemokratų dalyvavimo St. Seimo rinkimų kampanijoje aplinkybes ir ypatybes, galime apibendrintai teigti, kad, nepaisant visų čia minètų buvusių ir pačių socialdemokratų akcentuotų (kaip kad matème) nepalankių jiems aplinkybių, socialdemokratai, nors tarp jų ir buvo (kaip čia jau cituotame 1925 m. pranešime teigè K. Bielinis) „pradejus reikštis Steigiamojo Seimo rinkimų boikoto kryptis“ (kuri „buvo nugalèta“)"11 dalyvavo St. Seimo rinkimuose ir sugebejjo iškelti savo rinkimų sąrašus daugumoje - keturiose iš šešių rinkimų apygardų. Kaip jau minejjome, dèl komunistų veiklos ir dèl to, kad iki tol nespèta čia atkurti partijos vietinių organizacijų, dèl „jejgų trūkumo“ LSDP, anot K. Bielinio, „neištesèjo pastatyti“ rinkimų sąrašų dviejose - I (Marijampolès) ir IV (Telšių) - rinkimų apygardose ${ }^{72}$.

\section{Lietuvos socialdemokratų dalyvavimas St. Seimo rinkimų kam-} panijoje: kandidatų sąrašų ir kandidatų apibūdinimas

Trumpai apibūdinant LSDP rinkimų sąrašus atskirose rinkimų apygardose, pradžioje reikètų paminėti, kad II (Kauno) rinkimų apygardoje LSDP iškèlè 19-os kandidatų i St. Seimą sąrašą, III (Raseinių) rinkimų apygardoje - 14-os kandidatų sąrašą, V (Panevéžio) rinkimų apygardoje - 27-ių kandidatų sąrašą ir pagaliau paskutinejje VI (Utenos) rinkimų apygardoje - 14-os kandidatų sąrašą ${ }^{73}$.

71 Partijos organizacinès darbuotès apžvalga 1924-1925 metais, LCVA, f. 937, ap. 1, b. 34, 1. 29. Apie St. Seimo rinkimų boikoto idèją žr.: Ar ilgai bus sauvalybė? Darbas. 192002 11, Nr. 10, p. 1.

${ }^{72}$ Ten pat. Lietuvos teritorija St. Seimo rinkimams buvo suskirstyta i 10 rinkimų apygardų, tačiau keturių iš jų Lietuvos valdžia nekontroliavo - jos buvo okupuotos Lenkijos, dèl to rinkimai vyko tik šešiose rinkimų apygardose. Plačiau žr.: Sirutavičius, V. Rinkimai ị Steigiamajị Seimą: aktyvumo problema, p. 70-72.

73 Žr.: Socialdemokratas. 192004 14, Nr. 1, p. 1-2. Tolesnè šiame straipsnio skyrelyje pateikiama LSDP kandidatų i St. Seimą sąrašų analizė yra paremta čia publikuotais LSDP sąrašais. 
Net 15 socialdemokratų ị St. Seimą kandidatavo daugiau nei viename rinkimų LSDP sąraše, tai yra LSDP sąrašuose jie kandidatavo daugiau nei vienoje rinkimų apygardoje. Mat pagal St. Seimo rinkimų ìstatymą vienas kandidatas ị St. Seimą galèjo būti įrašytas net kelių, bet ne daugiau kaip penkių rinkimų apygardų vienos partijos (ar kokios nors kitokios grupès) sąrašuose. Tad trys žymūs socialdemokratų veikejjai - K. Venclauskis, K. Bielinis ir J. Byla - kandidatavo ì St. Seimą net trijose - Kauno, Panevėžio ir Raseinių - rinkimų apygardose. 12 aktyvesnių ir žymesnių socialdemokratų - S. Kairys, V. Požela, S. Digrys, J. Paknys, V. Bielskis, A. Povylius, P. Gudavičius, P. Mažylis, P. Bugailiškis, E. Šukevičius, J. Čiurlys ir J. Urbšys - ị St. Seimą kandidatavo dviejose rinkimų apygardose.

Iš viso į St. Seimą LSDP sąrašuose keturiose rinkimų apygardose kandidatavo 56 asmenys. Tarp jų matome tiek tuometinius partijos lyderius, tiek ir praeityje atskirais istoriniais laikotarpiais tokiais buvusius, $1918 \mathrm{~m}$. vasario 16-osios akto signatarą ir vieną iš pagrindinių jo autorių S. Kairị, taip pat ateityje būsimą žymų teisininką, advokatą, 1926 m. būsiantị vidaus reikalų ministru kairiųjų Vyriausybejje V. Poželą. Be to, čia matome vieną iš labiausiai 1905 m. revoliucinių ịvykių metu pasižymejjusị socialdemokratą, ateityje būsiantị vienu iš dviejų pagrindinių (šalia S. Kairio) LSDP lyderių, K. Bielinį, du buvusius II Rusijos Valstybès Dūmos narius, atstovavusius LSDP, - A. Povylių ir P. Gudavičių, žymius praeityje LSDP veikejjus vienu metu buvusiais vienais iš partijos lyderių - būsimą žymų teisininką bei istoriką A. Janulaitị ir žymų Lietuvos pramonininką V. Sirutavičių; žymiausius griežtai antibolševikiškai nusiteikusius lietuvių socialdemokratų veikejjus Rusijoje 1917-1918 m. pradžios laikotarpiu - buvusị Lietuvos karininkų sąjungos centro komiteto narị J. Bylą ir Lietuvių tautos tarybos Rusijoje, Lietuvių darbo žmonių tarybos Rusijoje narị, ateityje būsimą žymų Lietuvos bankininką ekonomistą S. Digrị.

Tarp socialdemokratų kandidatų i St. Seimą matome ir būsimąji paskutinị (laikotarpiu nuo 1938 m. gruodžio iki 1940 m. birželio) 
tarpukario Lietuvos Respublikos užsienio reikalų ministrą, o tuo metu jauną karininką J. Urbšį, ir būsimą žymų Lietuvos bankininką, būsimą Lietuvos banko valdytoją, o praeityje aktyvų LSDP veikèją, 1912 m. buvusị išrinktą kandidatu į LSDP CK narius J. Paknị. Taip pat tarp LSDP kandidatų ị St. Seimo narius matome būsimus žymius tarpukario Lietuvos mokslininkus, būsimus Kauno universiteto rektorius „fiziką-chemiką“ V. Čepinskị, chemiką A. Purèną.

Remiantis "Socialdemokrate" publikuotais LSDP rinkimų sąrašais atskirose rinkimų apygardose ir prie atskirų socialdemokratų kandidatų nurodytomis jų profesijomis ar užsiemmimais, galima atkreipti dèmesị $\mathfrak{i}$ tai, kad keturiuose socialdemokratų sąrašuose $\mathfrak{i}$ St. Seimą kandidatavo 9 darbininkai, 6 teisininkai, iš kurių vienas (K. Venclauskis) tuo metu èjo Šiaulių apskrities valdybos pirmininko pareigas, 7 mokytojai ir 2 aukštųjų kursų dèstytojai (V. Čepinskis, S. Digrys), 5 gydytojai, 4 inžinieriai, 4 (arba 5) tarnautojai, 3 valdininkai, 2 karininkai, 2 siuvẻjai, 1 geležinkelininkas, 1 matininkas, 1 kalvis, 1 knygrišys, 1 raštvedys, 1 kooperatorius, 1 ūkininkas, 2 (arba 1) mažažemiai ūkininkai, 3 buhalteriai ir 2 apskričių valdybų arba komitetų nariai.

Vis dèlto profesijos arba užsièmimo aspektu apibūdinant LSDP kandidatus ị St. Seimą, reikètų pabrèžti, kad pristatant LSDP rinkimų sąrašus skirtingose rinkimų apygardose tų socialdemokratų, kurie kandidatavo daugiau nei vienoje rinkimų apygardoje, užsièmimas dažnai buvo nurodomas skirtingai nei kad LSDP sąrašuose kitose rinkimų apygardose.

Pavyzdžiui, A. Povylius LSDP sąraše Kauno rinkimų apygardoje buvo nurodytas kaip buhalteris, o Panevėžio rinkimų apygardoje kaip mažažemis ūkininkas. J. Byla LSDP sąrašuose Panevėžio ir Kauno rinkimų apygardose buvo nurodytas kaip karo teismo tardytojas, o Raseinių apygardoje kaip tarnautojas. K. Bielinis Raseinių ir Panevėžio rinkimų apygardose buvo pristatytas kaip apskrities valdybos narys, o Kauno rinkimų apygardoje kaip buhalteris. K. Venclauskis 
Kauno ir Raseinių rinkimų apygardose LSDP sąrašuose buvo nurodytas kaip advokatas, o Panevėžio rinkimų apygardoje - kaip apskrities valdybos pirmininkas. Taip pat reikia pasakyti, kad, kaip matysime truputi vẻliau, prie kai kurių ì St. Seimą išrinktų socialdemokratų, pristatant juos kaip būsimus St. Seimo narius „Laikinosiose vyriausybès žiniose“ bei oficioze "Lietuva“, bus nurodytos kitokios profesijos ar kitokie užsièmimai, negu kad buvo nurodyta "Socialdemokrate“ publikuotuose LSDP rinkimų sąrašuose.

Aptarus LSDP dalyvavimo St. Seimo rinkimų kampanijoje ypatybes ir aplinkybes, apžvelgus LSDP rinkimų sąrašus ir šiek tiek apibūdinus ị St. Seimą kandidatuojančius socialdemokratus, galima pereiti prie glausto pačių St. Seimo rinkimų rezultatų apskritai ir detalesnio LSDP rezultatų šiuose rinkimuose apibūdinimo.

\section{Socialdemokratų dalyvavimo Steigiamojo Seimo rinkimuose rezultatai}

Taigi 1920 m. balandžio 14-16 d. vykusiuose St. Seimo rinkimuose, kuriuose iš viso balsavo 682291 Lietuvos pilietis (arba apie 90 proc. rinkejjų $\left.{ }^{74}\right)$, daugiausia balsų (317,3 tūkst., arba 46,50 proc. visų rinkimuose dalyvavusių rinkèjų balsų) gavo Krikščionių demokratų blokas (LKDP, LŪS, LDF), ị St. Seimą buvo išrinkti 59 jų atstovai, kas sudarè 52,7 proc. visų (112-os) St. Seimo narių mandatų skaičiaus ${ }^{75}$. LSLDP ir LVS blokas St. Seimo rinkimuose gavo 155,6 tūkstančio, arba 22,81 proc., rinkejjų balsų ir 29 St. Seimo narių mandatus, kas

${ }^{74}$ Oficialiais tarpukario statistiniais duomenimis, kuriems pritare ir dalis istorikų, St. Seimo rinkimuose dalyvavo daugiau nei 90 proc. piliečių (t. y. balsavimo teisę turinčių Lietuvos gyventojų). Kitų istorikų požiūriu (tvirtinimu), dalyvavo 90 proc. ne piliečių apskritai, o tik ị rinkèjų sąrašus ịtrauktų piliečių. Plačiau apie tai žr.: Sirutavičius, V. Rinkimai ị Steigiamajji Seimą: aktyvumo problema, p. 65-84; Sirutavičius, V. Dar kartą rinkimų i Steigiamaji Seimą klausimu. Steigiamajam Seimui-90. Vilnius, 2011, p. 39-49.

${ }^{75}$ Šie ir kiti toliau pateikiami duomenys apie St. Seimo rinkimų rezultatus paimti iš: Lietuvos statistikos metraštis. T. 1, 1924-1926, p. 72-73; Noreikienè, S. Min. veik., p. 97; Truska, L. Min. veik., p. 24-25; Čepėnas, P. Min. veik., p. 479. 
sudarè 25,9 proc. visų St. Seimo narių mandatų. LSDP, už kurią balsavo apytiksliai 87,1 tūkstančio rinkejjų (tiksliai - 87051 rinkèjas), arba 12,77 proc. visų rinkimuose dalyvavusių rinkèjų, gavo 13 St. Seimo narių mandatų. A. Smetonos vadovaujamos Lietuvos tautos pažangos partijos (LTPP), gavusios apie 12 tūkstančių rinkejjų balsų (1,76 proc.), ir Demokratinès lietuvių tautos laisvès santaros (DLTLS), gavusios tik apie 2,6 tūkstančio rinkejjų balsų (0,38 proc.), atstovų ì St. Seimą nebuvo išrinkta. Keletą mandatų gavo tautinių mažumų atstovai: Žydų demokratinis susivienijimas, surinkęs 44,7 tūkstančio (6,55 proc.) rinkejjų balsų, gavo 6 mandatus, Lenkų centrinis rinkimų komitetas, gavęs apie 32 tūkstančius (2,6 proc.) balsų, gavo 3 mandatus, Lietuvos vokiečių komitetas, surinkęs 7,2 tūkstančio (1,06 proc.) rinkèjų balsų, gavo 1 St. Seimo nario mandatą.

Taigi atsižvelgiant $\mathfrak{i}$ tuometinę LSDP organizacinę būklę ir kitas jai nepalankias aplinkybes bei sunkumus, su kuriais, kaip mateme, šiai partijai teko susidurti St. Seimo rinkimų kampanijoje, galima teigti, kad, bendrai paèmus, čia paminèti LSDP dalyvavimo St. Seimo rinkimuose visos Lietuvos mastu rezultatai skaitmenine ir procentine išraiška laikytini palyginti sėkmingais. Pereinant prie detalesnio LSDP dalyvavimo St. Seimo rinkimuose pristatymo, reikia atkreipti dėmesị $\mathfrak{i}$ tai, kad LSDP sąrašas daugiausia rinkejjų balsų gavo V (Panevėžio) rinkimų apygardai priklausiusioje Šiaulių apskrityje - 31,6 proc. šios apskrities rinkejjų balsų ir Biržų apskrityje - 31,0 proc. šios apskrities rinkejjų balsų ${ }^{76}$. Šiose apskrityse LSDP sąrašai tiek pagal gautą rinkèjų balsų skaičių ir procentą užèmė pirmas vietas tarp visų čia rinkimuose dalyvavusių rinkimų sąrašų. Tarp visų lietuviškų rinkimų sąrašų LSDP sąrašas, gavęs 19,6 proc. rinkẻjų balsų, pirmą vietą užėmė ir Kauno mieste, taip pat Panevéžio mieste, kur jis gavo 22,3 proc. rinkèjų balsų. Kauno mieste LSDP sąrašas gavo daugiau rinkèjų balsų netgi negu visi trys Krikščionių demokratų bloko sąrašai kartu

${ }^{76}$ Socialdemokratu gauti rezultatai St. Seimo rinkimuose pagal atskiras apskritis ir miestus čia ir toliau paimti iš: Noreikienè, S. Min. veik., p. 98. 
sudèjus (12,6 proc.). LSDP sąrašas gana daug rinkèjų balsų gavo Šiaulių mieste $-26,8$ proc. ir Rokiškio apskrityje - 25,6 procento. Šiaulių mieste ir Rokiškio apskrityje LSDP sąrašai užèmė antras vietas tarp visų čia rinkimuose dalyvavusių atskirų rinkimų sąrašų.

Nemažai rinkẻjų balsų - 27,9 proc. LSDP sąrašas gavo Kèdainių apskrityje, čia tarp visų šioje apskrityje rinkimuose dalyvavusių rinkimų sąrašų jis užèmè trečią vietą. Trečią vietą, gavęs atitinkamai 26,0 proc. ir 19,6 proc. rinkèjų balsų, LSDP sąrašas užèmė ir Ukmergès miesto bei Vilkaviškio apskrityje. Daugiau kaip 10 proc. rinkejjų balsų LSDP sąrašas dar gavo Šakių apskrityje (15,0 proc.) ir Ukmergès apskrityje. Mažiau nei 10 proc., tačiau daugiau nei 5 proc. rinkèjų balsų LSDP sąrašas gavo Panevėžio apskrityje (9,6 proc.), Utenos apskrityje (8,7 proc.), Trakų apskrityje (8,7 proc.), Kauno apskrityje (7,5 proc.), Ežerėnų (Zarasų) apskrityje (7,2 proc.), Raseinių apskrityje (6,2 proc.). Mažiau nei 5 proc. rinkèjų balsų LSDP sąrašas tegavo tik Tauragès apygardoje (1,0 proc.). Kadangi dviejuose rinkimų apygardose - Marijampolès ir Telšių - socialdemokratai, anot K. Bielinio, dèl „jègų trūkumo“ „neištesėjo pastatyti“ rinkimų sąrašų ${ }^{77}$, tai šioms rinkimų apygardoms priklausiusiose Alytaus, Marijampolès, Seinų, Kretingos, Mažeikių ir Telšių apskrityse LSDP sąrašų St. Seimo rinkimuose nebuvo.

Apibendrindami žvilgsnị ị LSDP rinkimų sąrašų rezultatus pagal atskirus miestus ir apskritis, galime kartu su istorike S. Noreikiene teigti, kad „socialdemokratai patraukè ị savo pusę tam tikrą miestų gyventojų dalį“ ir kad „nemažas balsavusiųjų už LSDP skaičius buvo Kèdainių, Biržų, Šiaulių apskrityse" ${ }^{\text {"78. }}$.

Daugiausia rinkèjų balsų socialdemokratai gavo V (Panevéžio) rinkimų apygardoje (ị ją, be Panevėžio ir Šiaulių miestų, ịejo Biržų, Panevėžio ir Šiaulių apskritys), tad čia LSDP gavo daugiausia ir St. Seimo nario mandatų - 6 iš 24 . Čia ị St. Seimą buvo išrinkti socialde-

77 Partijos organizacinès darbuotès apžvalga 1924-1925 metais, LCVA, f. 937, ap. 1, b. $34,1.29$.

${ }^{78}$ Noreikienè, S. Min. veik., p. 97. 
mokratai K. Venclauskis, V. Požela, V. Sirutavičius, K. Bielinis, P. Šemiotas ir J. Daukšys ${ }^{79}$. Tris mandatus iš 20-ies socialdemokratai gavo II (Kauno) rinkimų apygardoje, j̣ kurią ièjo Kauno miestas ir Kauno, Šakių, Trakų ir Vilkaviškio apskritys. Čia buvo išrinkti V. Čepinskis, J. Plečkaitis ir J. Pakalka ${ }^{80}$. Po du LSDP atstovus ị St. Seimą buvo išrinkta VI (Utenos) ir III (Raseinių) rinkimų apygardose. Čia buvo išrinkti atitinkamai S. Kairys ir A. Purènas bei B. Cirtautas ir S. Digrys.

Nors tuometinė LSDP organizacinè ir politinẻ būklè buvo prasta, vis dèlto galime tvirtinti, kad, atlaikiusi valdžios trukdymus, komunistų puolimus ir LDF konkurenciją dèl ịtakos darbininkijai, St. Seimo rinkimuose LSDP pasirode palyginti gerai, atsižvelgiant ị visas tas sèkmingam jos dalyvavimui nepalankias sąlygas ir aplinkybes.

Jeigu LSDP būtų iškèlusi savo kandidatų sąrašus ir Marijampolès bei Telšių rinkimų apygardose, tai labai tikètina jos gautų rinkèjų balsų skaičius ir procentas, kaip ir gautų St. Seimo narių mandatų skaičius, būtų buvęs didesnis. Vèlesnio St. Seimo LSDP frakcijos sekretoriaus J. Pakalkos tvirtinimu, „galima teigti, kad suspejjus įteikti kandidatų sąrašus" Marijampolès ir Telšių rinkimų apygardose LSDP frakcija „būtų padidejusi dar bent dviems nariais“" ${ }^{\text {"81 }}$.

Marijampolès rinkimų apygarda buvo viena iš tų rinkimų apygardų, kuriose St. Seimo rinkimuose LSDP nedalyvavo. Tad St. Seimo 24-ame posėdyje minètas LSDP frakcijos narys J. Pakalka, atstovavęs frakcijai St. Seimo narių mandatų patikrinimo komisijoje, pareiškè, kad, socialdemokratų požiūriu, per St. Seimo rinkimus ne visai teisingai ir demokratiškai buvo paskirstyti mandatai, nes Marijampolès apygardoje buvo išrinktas 21 St. Seimo atstovas, oficialiai teigiant, kad jie atstovauja apytiksliai 318 tūkstančių gyventojų, o, anot socialdemokratų, realiai tai buvo atstovaujama tik 186 tūkstančiams gyventojų, taigi čia turèjo būti išrinkta tik 12 mandatų, tai yra 9 mandatais

79 Žr.: Lietuva, 192005 09, Nr. 102, p. 1.

80 Žr.: Lietuva, 192005 04, Nr. 97, p. 1.

${ }^{81}$ Pakalka, J. Min. veik., p. 69. 
mažiau, negu kad buvo išrinkta ${ }^{82}$. Todèl J. Pakalka siūlè priimti atitinkamą St. Seimo rezoliuciją ir devynių atstovų mandatus pripažinti neteisètais ${ }^{83}$. Tačiau šio socialdemokratų pasiūlymo St. Seimo dauguma, kaip ir reikèjo tikètis, neprièmé, o pats šio pasiūlymo pagrịstumo klausimas reikalautų specialaus tyrimo.

Apibūdinę socialdemokratų dalyvavimą St. Seimo rinkimuose statistiniu požiūriu, pažvelkime ì tai, kaip patys socialdemokratai vertino rinkimų rezultatus.

\section{Socialdemokratų pateiktas St. Seimo rinkimų ir jų rezultatų vertinimas}

Savaime suprantama, kad pagrindinis šaltinis, iš kurio galime spręsti apie tai, kaip patys socialdemokratai vertino St. Seimo rinkimus, jų rezultatus, taip pat ir savo pačių gautus rezultatus, yra tuo metu neoficialiu LSDP laikraščiu buvęs „Socialdemokratas“.

Taigi 1920 m. balandžio 24 d. "Socialdemokrate“ išspausdintame straipsnyje „Rinkimams pasibaigus“ buvo rašoma, kad St. Seimo rinkimai „neatvaizdina gerai ir teisingai visų krašto santykių, nes nebuvo galimybių pasirodyti jiems visoj pilnumoj ir aiškumoj“, mat „darbininkai - jų draugijos, spauda - negalèjo né atsidusti, buvo smaugiami“"84. Minètame straipsnyje buvo dèstoma, kad „žvalgyba šitoji kolčiakų - krikščionių ìstaiga po senovei kišo mūsų draugus ị kalèjimą lyg nieko nebūtų atsimainę“. O „kitoj padèty“, anot socialdemokratų laikraščio, „buvo valdiškosios partijos - krikščionys ir pažanga“, kurios „laisvai nuo senai galejo agituoti“, nes jų rankose buvo valdžia ir „jos turèjo visokių priemonių, kurių neturèjo kitos [partijos - G. M. pastaba]“.

Šiame straipsnyje vèl buvo akcentuojama, kad krikščionys demokratai per St. Seimo rinkimų kampaniją „pavertė bažnyčias ị agitacijos

${ }_{82}$ Ten pat; Steigiamojo Seimo darbai (toliau-SSD), 24 p-dis, 192007 07, p. 219.

83 Ten pat.

${ }^{84}$ Rinkimams pasibaigus. Socialdemokratas. 192004 29, Nr. 3 (17), p. 2. 
vietas ir neturèdami konkurentų su Dievo pagalba galejjo ramiai dirbti savo partijos naudai“. Tautos pažangos partija, pasak socialdemokratų, „neturèdama dangiškos pagalbos turejo naudotis valstybiniu aparatu, jo priemonėmis“. Tačiau, kaip teigiama "Socialdemokrato“ straipsnyje, vis dèlto „valdiškos partijos prakišo“, kaip „prakišo ir visos palaidosios grupès ir grupelès, kurios èjo ị rinkimus nežinodamos, ko eina ir ką duoda“. Anot raide C pasirašiusio šio straipsnio autoriaus, rinkimai į St. Seimą „ejo ne asmenimis, bet partijomis, turinčiomis aiškią politikos programą, dirbusiomis Lietuvoje ir įrodžiusiomis, kad turi atramą žmonèse“.

Toliau straipsnyje buvo rašoma, kad „gyvenimui buvo svetimi pavieni žmonès, geri ar blogi, svajotojai ir laimès ieškotojai, kurie tik save nešè, o paskui savęs nesivedè, kas juos laiduotų“. Tokius, straipsnio autoriaus žodžiais, „rinkimai išmetė ar net sutriuškino visai“ ir „jiems gyvenime ne vieta“. Straipsnyje dèstoma, kad „Pažanga“, kuri „buvo taip stipri valdžioje, kuri išvien su krikščionimis artimoj prietelystejje trukdè Lietuvos atstatymą, liaudies ant kojų atsistojimą, smaugè darbininkus, rinko karalius, meilinos prie kolčiakų užsieniuose ir Lietuvoje prie dvarininkų ieškodama paspirties visur tik ne Lietuvoje, ne darbo žmonèse, šitoji partija žuvo visai, nes negavo nė vieno atstovo“. Tai „Socialdemokrate“ buvo traktuojama kaip rinkèjų įvykdytas „visos valdžios politikos pasmerkimas“.

Straipsnyje „Rinkimams pasibaigus“ buvo ịvertintas ir Demokratinès lietuvių tautos laisvès santaros dalyvavimas rinkimuose. Ši partija buvo apibūdinta kaip „liberalų inteligentų paradas, užsinorejjusių viešpatauti ant žmonių, bet ị žmones nejjusių“. Todèl ir „žmonės pro juos praejo“ ir ši partija taip pat negavo nè vieno atstovo. Čia cituojamame straipsnyje buvo išsakoma hipotezė, kad galbūt „pasimokinę iš rinkimų“ „santariečiai grị̌ i gimtąj̣ lizdą, iš kurio buvo išèję, ị demokratus liaudininkus“.

Straipsnio, skirto rinkimų i St. Seimą išdavoms aptarti, autoriaus nuomone, rinkimuose dalyvavusi „lenkų partija“ buvo dvarininkų, 
siekusių išgelbèti savo dvarus, prisidengiant „tautine lenkų skraiste“, partija, kuri „liaudyje nedaug terado šalininkų“.

Kaip rašoma minètame straipsnyje, „visa kova rinkimuose ejjo tik tarp trijų partijų - krikščionių demokratų, liaudininkų ir socialdemokratų, kur socialdemokratai daugiausia veike tarp darbininkų, liaudininkai - tarp valstiečių, krikščionys, pridirbę keleto partijų, veikè tarp abiejų visuomenès klodų, norèdami sulipdyti tikybiniu kitu“. Bendra, kaip teigiama "Socialdemokrato“ straipsnyje, šiose „varžytinèse“ buvo „aštrus valdžios politikos pasmerkimas“, nes ir „krikščionys turintys gerą uoslę išsižadejo savo draugų ir auklètinių valdžioje - visokių draugelių, merkių: taip jie žmonėms igriso, jog užtardami šiuos būtų prakišę rinkimus“. Taigi, toliau dėstoma straipsnyje, „rinkimai praejo opozicijos obalsiais“, tokioje situacijoje „žmonès rinko net ir krikščionis, tik norejo darbo žmonių, kurie eitų prieš ponus, o ne zakristijonų, klebonų interesų gynėjų“.

Straipsnio „Rinkimams pasibaigus“ autoriaus tvirtinimu, nors Seime krikščionys demokratai ir turès daugumą, tačiau visoje Lietuvoje jie daugumos neturi ir kad tik per „nesusipratimą ir dèl vylių jie surinko daugiau balsų“. Kita vertus, straipsnio autorius pabrěžia, kad „jau dabar aiškiai matoma, kaip „krikščioniškasis“ kitas trupa ir byra, (ir) neužilgo turès trūkti“. Mat „krikščionys nori apimti neapimamą daiktą - nori suvaryti ị vieną krūvą dvarininkus, didelius ir mažus ùkininkus, kunigus ir darbininkus - kurių grupiniai, klasiniai ir asmens interesai nèra vienodi“.

Pasak apžvelgiamo straipsnio autoriaus, čia susidarančius „plyšius ir tarpus“ galèjo „laikinai pridengti smarkiai varomoji demagogija“, tačiau tai „negali būti ilgiau“ ir kad „galingieji demagogai turès apmokèti išduotąji vekselį“. Straipsnyje „Rinkimams pasibaigus“ prognozuojama, kad „apviltieji darbininkai, patekę i „Darbo Federaciją“, jeigu norès ginti darbininkų reikalus šiek tiek prasilavinę, prasitrynę turès mesti šalin dvarininkus, pirklius, klebonus ir storakaklius ūkininkus, kreiptis kairèn, tenai ieškoti atramos“ ir kad „gyvenimas 
spirs darbininkus sudaryti vieną partiją, kovojančią prieš buržuaziją, kurios reiškejjai tuo tarpu yra krikščionys", kurie, straipsnio autoriaus spejjimu, turejjo sudaryti bendrą „bloką su dvarininkais ir miesto pirkliais prieš darbininkus“.

Taigi toks tat lietuviškai socialdemokratinis St. Seimo rinkimų rezultatų vertinimas buvo pateiktas $1920 \mathrm{~m}$. balandžio $29 \mathrm{~d}$. „Socialdemokrato“ numeryje. Vis dèlto pridedami dar vieną kitą štrichą išsamesniam šio vertinimo vaizdui, turime pridurti, kad socialdemokratai pateikè ir tam tikrą teigiamą šių rinkimų rezultatų vertinimą. Kaip kad buvo rašoma 1920 m. gegužès 12 d. „Socialdemokrate“, „nežiūrint to, kad Seimo rinkimai buvo sudaryti ir pravesti mūsų priešų ir aiškiai darbo žmonių nenaudai, vis tik 15 gegužès bus sẻkminga Lietuvos gyvenimui diena“ ir su būsimu St. Seimo darbu „Lietuvos proletarai“ gaus „vieną neabejojamą daiktą - patogesnes sąlygas pasiruošti kovai su savo priešais, sustiprinti savo pajėgas ir eiti kovon atvirai didelèmis ir tvarkingomis miniomis ${ }^{\text {“85. }}$.

Baigdami apibūdinti socialdemokratų pateiktą St. Seimo rinkimų rezultatų vertinimą, be abejo, turime akcentuoti, kad tai buvo to meto socialdemokratinis požiūris ị rinkimų rezultatus ir kad šio požiūrio pristatymas jokiu būdu nereiškia, jog šiuos rezultatus būtent taip ir reikia vertinti. Čia pateiktas tuometinis socialdemokratinis požiūris i St. Seimo rinkimų rezultatus leidžia savotiškai autentiškai pailiustruoti to meto socialdemokratų politines-ideologines nuostatas ir kartu padeda geriau suprasti tiek rinkimų i St. Seimą laikotarpio, tiek apskritai šio Seimo darbo laikotarpio lietuvių socialdemokratų politinę laikyseną, ir tuo aspektu pateikti ši požiūrị yra naudinga.

Apibūdinę tai, kaip patys socialdemokratai vertino St. Seimo rinkimų rezultatus, pereikime prie socialdemokratų, išrinktų i St. Seimą, apibūdinimo.

${ }^{85}$ Keliui nusišviečiant. Socialdemokratas. 192005 12, Nr. 5(19), p. 1. 


\section{Steigiamąji Seimą išrinkti socialdemokratai: asmenybès ir frakcija}

I St. Seimą buvo išrinkti šie LSDP atstovai: Bielinis Kipras, 36 m., kokio nors specialaus išsilavinimo nebuvo igijęs, V. DaugirdaitèsSruogienès knygoje apie Lietuvos St. Seimą profesiniu ir užsièmimo požiūriu apibūdintas kaip „visuomenès darbuotojas“, oficialiuose ị St. Seimą išrinktų asmenų sąrašuose, skelbtuose „Vyriausybės žiniose“ ir oficioze „Lietuva“, šiuo požiūriu nurodomas kaip buhalteris, iki išrinkimo ị St. Seimą dirbęs Šaulių apskrities valdybos nariu, atsakingu už finansus ${ }^{86}$; Cirtautas Bronius, 39 m., laikomas teisininku, nors teisès mokslų nebuvo baigęs, nuo $1918 \mathrm{~m}$. pabaigos iki išrinkimo ị St. Seimą dirbęs taikos teisèju Kèdainiuose; Čepinskis Vincas, 49 m., „fizikochemikas“, Aukštųjų kursų lektorius; Daukšys Jurgis, 32 m., darbininkas; Digrys Stasys, 34 m., ekonomistas, valdininkas, Aukštųjų kursų lektorius; Kairys Steponas, 43 m., inžinierius, laikotarpiu iki St. Seimo darbo pradžios buvo atsidejęs politinei veiklai; Pakalka Jonas, 26 m., „Vyriausybės žiniose“ ir „Lietuvoje“ skelbtuose oficialiuose ị St. Seimą išrinktų asmenų sąrašuose nurodomas kaip valdininkas, „Socialdemokrate“ skelbtuose LSDP kandidatų St. Seimą sąrašuose apibūdintas kaip tarnautojas; Plečkaitis Jeronimas, 32 m., mokytojas, 1919 m. dirbęs darbo ir socialinès apsaugos inspektoriumi Vilkaviškyje, paskutinius pusę metų iki St. Seimo rinkimų buvo (vengdamas suemimo) pasitraukęs ị Vokietiją, gyveno Berlyne; Požela Vladas, 41 m., juristas (teisininkas); Purènas Antanas, 37 m., chemikas (V. Daugirdaitès-Sruogienès knygoje traktuojamas kaip inžinierius), mokytojas, nuo 1919 m. rugpjūčio èjęs Rokiškio gimnazijos direktoriaus pareigas; Sirutavičius Vladas, 43 m., inžinierius, pramonininkas; Venclauskis Kazimieras, 40 m., teisininkas (prisie-

${ }^{86}$ Duomenys apie socialdemokratus, išrinktus ị St. Seimą, paimti iš išrinktų St. Seimo narių sąrašo, išspausdinto ,Vyriausybės žiniose“ ir „Lietuvoje“. Žr.: Vyriausybès žinios. 192005 16, Nr. 31, p. 2; Steigiamojo Seimo narių sąrašas. Lietuva. 192005 15, Nr. 106, p. 2. Taip pat žr.: Daugirdaitė-Sruogienė, V. Min. veik., p. 41, 43, 47. 
kęs advokatas), paskutinius metus iki išrinkimo ị St. Seimą ėjęs Šiaulių apskrities valdybos pirmininko pareigas; Šemiotas Pranas, 25 m. amatininkas (kalvis).

Vèliau vietoj $1920 \mathrm{~m}$. spalio $13 \mathrm{~d}$. pasitraukusio iš St. Seimo narių A. Purèno ir $1921 \mathrm{~m}$. sausio $17 \mathrm{~d}$. pasitraukusio V. Sirutavičiaus socialdemokratams St. Seime atitinkamai nuo $1920 \mathrm{~m}$. spalio $13 \mathrm{~d}$. ir $1921 \mathrm{~m}$. gegužès $24 \mathrm{~d}$. atstovavo Šukevičius Eduardas, 33 m., tuo metu buvęs žurnalistu, „Socialdemokrato“ leidejju bei redaktoriumi, ir Povylius Antanas, 39 m., 1920 m. LSDP rinkimų sąrašuose figūravęs vienur kaip buhalteris, kitur kaip mažažemis ūkininkas, V. Daugirdaitès-Sruogienès knygoje priskirtas valdininkams ${ }^{87}$.

Pirmaisiais St. Seimo darbo mėnesiais (1920 m. gegužę-rugsèjị) Socialdemokratų frakcijai priklausè pagal „Darbo žmonių“ sąrašą išrinktas socialistas liaudininkas (bet ne socialistas liaudininkas demokratas) Kazys Lekeckas, 43 m., valdininkas ${ }^{88}$. Taigi minetais mènesiais LSDP frakciją St. Seime sudarè 14 atstovų. Vèliau, kai K. Lekeckas $1920 \mathrm{~m}$. rugsèji atsisakè St. Seimo nario mandato, vietoj jo St. Seimo nariu pagal minètą sąrašą išrinktas K. Zubauskas LSDP frakcijos nariu netapo, nes, anot šios frakcijos sekretoriaus J. Pakalkos vèlesnio tvirtinimo, „jis ị socialdemokratų frakciją nebuvo priimtas" ${ }^{\text {" }}$.

Apibūdinant ị St. Seimą išrinktus socialdemokratus, reikètų atkreipti demesị i toki aspektą kaip jų išsilavinimas. Anot istorikès V. Daugirdaitès-Sruogienès, išsilavinimo požiūriu LSDP frakcijos St. Seime nariai atrodè taip: 7 buvo baigę aukštąji mokslą; 1 - nebaigęs aukštojo; 2 - pradejję, bet nebaigę vidurinès mokyklos; 4 - baigę pradinę mokyklą, 1 - savamokslis ${ }^{90}$.

${ }_{87}$ Žr.: Vyriausybės žinios. 192106 16, Nr. 66, p. 3; Daugirdaitè-Sruogienè, V. Min. veik., p. 41.

${ }^{88}$ Pakalka, J. Min. veik., p. 69-70; Blažytė, D. Min. veik., p. 43.

${ }^{89}$ Pakalka, J. Min. veik., p. 70.

${ }^{90}$ Daugirdaitè-Sruogienè, V. Min. veik., p. 47. 
Tačiau iš tiesų yra tam tikrų neaiškumų, kaip traktuoti kai kurių i St. Seimą išrinktų socialdemokratų išsilavinimą. Akivaizdu yra viena, kad 7 LSDP frakcijos nariai (V. Čepinskis, V. Sirutavičius, S. Kairys, A. Purènas, V. Požela, S. Digrys, K. Venclauskis) tiksliai buvo baigę aukštąji mokslą ${ }^{91}$. Tiesa, istorinejje literatūroje galime rasti ir tvirtinimų, kad aukštąji mokslą buvo baigę 8 St. Seimo LSDP frakcijos nariai, prie išvardintų 7 socialdemokratų pridedant dar B. Cirtau$\mathrm{tą}^{92}$. Vis dèlto turimi istoriniai duomenys ne tik kad neleidžia teigti, kad B. Cirtautas būtų baigęs aukštąji mokslą. Maža to, atrodo, kol kas nerasta žinių, kad jis būtų jị ir pradèjęs. Panašu ị tai (hipotetinè prielaida), kad B. Cirtautas teisininku tapo ir taikos teisejju $1918 \mathrm{~m}$. pabaigoje buvo paskirtas dèl to, kad su teisininko (privataus advokato) darbo praktika jis susidūrè dirbdamas garsaus lietuvių teisininko P. Leono sekretoriumi ${ }^{93}$.

Yra tam tikrų neaiškumų ir dèl to, kaip traktuoti ir kitų socialdemokratų, tapusių St. Seimo nariais, išsilavinimą. Pavyzdžiui, oficialiuose ị St. Seimą išrinktų asmenų sąrašuose J. Plečkaitis nurodomas kaip mokytojas, jis 1902 m. buvo baigęs dviklasę mokyklą Virbalyje ir 1917 m. pavasarị vokiečių okupacinès valdžios ịsteigtus mokytojų kursus lietuviams ${ }^{94}$. Kaip traktuoti jo igytą išsilavinimą pagal išsilavinimo gradavimą schemoje - pradinis, vidurinis, aukštasis išsilavinimas, neaišku, kaip ir neaišku, kuriai pagal išsilavinimą išskirtai St. Seimo narių socialdemokratų grupei ji priskyrè V. DaugirdaitèSruogiené.

91 Žr.: Socialdemokratai Lietuvos Respublikos Seimuose, p. 114, 121, 136, 170, 175, $184,191$.

92 Žr.: Daugirdaitė-Sruogienė, V. Min. veik., p. 46; Vilčinskas, J. Min. veik., p. 125; Blažytè, D. Min. veik., p. 43; Kašauskienè, V. Min. veik., p. 87.

93 Žr.: Tamošaitis, M.; Selenis, V. Cirtautas Bronislavas. Socialdemokratai Lietuvos Respublikos Seimuose, p. 111; Tamošaitis, M.; Selenis, V. Cirtautas Bronislavas. Lietuvos Steigiamojo Seimo (1920-1922 metu) narių biografinis žodynas, p. 117.

94 Tamošaitis, M.; Plečkaitis, J. Socialdemokratai Lietuvos Respublikos Seimuose, p. 161; Tamošaitis, M. Plečkaitis Jeronimas, Lietuvos Steigiamojo Seimo (1920-1922 metu) narių biografinis žodynas, p. 267. 
Neaiškumų kelia ir žinios apie kai kurių kitų i St. Seimą išrinktų socialdemokratų išsilavinimą. Vis dèlto apskritai, anot istorikų, LSDP frakcija buvo labiausiai išsilavinusi Seimo frakcija - net 61,50 proc. jos narių buvo baigę aukštąsias mokyklas ${ }^{95}$. Tiesa, taip teigianti istorikè D. Blažytė ị aukštąji mokslą baigusių sąrašą ịtraukia ir B. Cirtautą, nors, kaip jau minejjome, neturime žinių, kad jis būtų baigęs aukštąji mokslą.

Be to, istorinejje literatūroje yra išsakyta tam tikrų diskutuotinų dalykų ir apibūdinant ị St. Seimą išrinktus socialdemokratus igytos profesijos požiūriu. Štai V. Daugirdaitė-Sruogienè, pristatydama atskirų St. Seimo frakcijų sudètị pagal profesijas, nurodo, kad tarp socialdemokratų, išrinktų ị St. Seimą, buvo 4 inžinieriai, 3 teisininkai, 1 mokytojas, 1 „visuomenès darbuotojas“, 1 ekonomistas, 1 amatininkas, 1 darbininkas, 1 žurnalistas ir 2 priskirti jungtinei „valdininkų, kooperatininkų ir savivaldybininkų grupei ${ }^{\text {"96 }}$. Susipažinimas su St. Seimo LSDP frakcijos narių biografijomis leidžia teigti, kad V. Daugirdaitè-Sruogienè, grupuodama juos pagal profesijas, „fizikochemiką" V. Čepinskį ir chemiką A. Purèną priskyrè prie inžinierių ${ }^{97}$, nors, matyt, kad tikrai teisingiau juos profesiniu požiūriu apibūdinti kitaip: V. Čepinskị - kaip mokslininką („fizikochemiką“) ir Aukštųjų kursų dèstytoją, o A. Purèną - kaip chemiką, mokytoją, švietimo sistemos darbuotoją ${ }^{98}$. Tad tikrais inžinieriais iš St. Seime dirbusių socialdemokratų laikytini tik S. Kairys ir V. Sirutavičius.

Istorinèje literatūroje trys LSDP frakcijai priskiriami teisininkai, kaip matėme, buvo V. Požela, K. Venclauskis ir B. Cirtautas (nors pastarasis teisininko diplomo, kaip jau čia ne kartą minejjome, ir nebuvo gavęs). Nekylant kokių nors didesnių neaiškumų, kas iš LSDP

95 Blažytė, D. Min. veik., p. 43.

${ }^{96}$ Daugirdaitè-Sruogienè, V. Min. veik., p. 46.

97 Ten pat.

98 Žr.: Mitrulevičius, G. Čepinskis Vincas, Socialdemokratai Lietuvos Respublikos Seimuose, p. 114; Tamošaitis, M. Purènas Antanas, Socialdemokratai Lietuvos Respublikos Seimuose, p. 175. 
frakcijos St. Seime buvo ekonomistas, darbininkas, amatininkas, mokytojas ar žurnalistas (visa tai aiškiai matyti iš anksčiau pateikto socialdemokratų, išrinktų i St. Seimą, pristatymo), reikètų pabrèžti, kad V. Daugirdaitės-Sruogienès pateiktame LSDP frakcijos narių grupavime pagal profesijas kaip „,visuomenès darbuotojas“, matyt, kad buvo nurodytas K. Bielinis, o „valdininkų, kooperatininkų ir savivaldybininkų grupei“ ši istorikè veikiausiai priskyrè J. Pakalką ir A. Povylių. Taip pat panašu, kad ị Socialdemokratų frakcijos narių grupavimą profesiniu požiūriu V. Daugirdaitè-Sruogienė neịtraukè trumpai šioje frakcijoje dirbusio, LSDP nepriklausiusio socialisto liaudininko mokytojo, rašytojo ir valdininko K. Lekecko.

Dar vienu ar kitu aspektu apibūdinant ị St. Seimą išrinktus Socialdemokratų frakcijos narius, galima paminèti, kad du iš jų - V. Sirutavičius ir P. Šemiotas (nors tuo metu pastarasis buvo paprastas amatininkas - kalvis) buvo bajoriškos kilmès, kad vienas iš šios frakcijos narių - A. Povylius 1907 m. buvo II Rusijos Valstybès Dūmos nariu ir kad net 6 (K. Bielinis, B. Cirtautas, S. Digrys, J. Plečkaitis, A. Povylius, V. Požela) St. Seimo LSDP frakcijos nariai už savo revoliucinę socialdemokratinę veiklą 1905-1906 m. buvo suimti ir ilgiau ar trumpiau kalinti carinès Rusijos kalejimuose ${ }^{99} .1905$ m. rudenị trumpam buvo suimtas ir E. Šukevičius ${ }^{100}$. S. Digrys ne tik sejdejjo carinès Rusijos kalèjimuose, bet $1918 \mathrm{~m}$. jam teko kalèti ir bolševikinejje Rusijoje $^{101}$. J. Plečkaitis ne tik kalèjo 1906-1909 m., bet jam dar teko 6 savaites sèdèti ir Kauno sunkiųjų darbų kalèjime 1918 m. pabaigoje - 1919 m. pradžioje ${ }^{102}$. Taigi matome, kad tarp socialdemokratų, išrinktų ị St. Seimą, ne vienas buvo pasižymėjęs revoliucine-social-

${ }^{99}$ Žr.: Socialdemokratai Lietuvos Respublikos Seimuose, p. 105, 111, 121, 161, 168, 171.

${ }^{100}$ Ten pat, p. 189.

${ }^{101}$ Mitrulevičius, G. Digrys Stasys, Socialdemokratai Lietuvos Respublikos Seimuose, p. 122.

${ }^{102}$ Tamošaitis, M. Plečkaitis Jeronimas, Socialdemokratai Lietuvos Respublikos Seimиоse, p.161. 
demokratine veikla revoliucingaisiais 1905-1906 m. Lietuvoje ir ne vienas iš jų už savo socialdemokratinę veiklą buvo ir nukentėjęs.

Pereidami nuo socialdemokratų, išrinktų i St. Seimą, kaip asmenybių ir kai kuriais aspektais jų visumos apibūdinimo prie pačios frakcijos susiformavimo ir jos veiklos St. Seime pradžios apibūdinimo, akcentuokime, kad LSDP frakcija susidarė pirmomis St. Seimo posèdžių dienomis. Jos pirmininku buvo išrinktas K. Venclauskis, buvęs Šiaulių burmistras, advokatas ir, anot frakcijos sekretoriumi išrinkto J. Pakalkos, „kietas žemaitis“103. K. Venclauskis, J. Pakalkos žodžiais, „ne tik frakcijos posėdžius gebejo tvarkyti, bet ir Seimo plenume autoritetingai jos nuomonę pareikšti“. Vienas žymiausių socialdemokratų veikejjų S. Kairys, to paties frakcijos sekretoriaus teigimu, „pasième“ frakcijos vicepirmininko pareigas ir buvo „ideologinès linijos formuotojas ir faktiškas lyderis“. J. Pakalkos nuomone, S. Kairys „buvo išimtinai atsidavęs partijos Centro komiteto pirmininko darbui“"104.

Reikia pasakyti, kad renkant St. Seimo prezidiumą S. Kairiui buvo pasiūlytos Seimo pirmojo vicepirmininko pareigos, tačiau LSDP lyderis jų atsisake $\dot{1}^{105}$. Socialdemokratai ì Seimo prezidiumą sutiko deleguoti tik vieną iš dviejų sekretorių su patariamojo balso teise. Juo išrinktas B. Cirtautas ${ }^{106}$. Kaip rašyta „Socialdemokrato“ laikraštyje, „socialdemokratai, kad ir kviečiami dalyvauti prezidiume, atsisakë“ ir „tik informacijos tikslais laiko jame savo žmogų, kaipo antrąji sekretorių be sprendžiamojo balso" ${ }^{\prime 07}$.

Apibūdinant LSDP frakcijos santyki su St. Seimo darbui vadovaujančių organų formavimu, reikia pabrèžti, kad LSDP frakcijos pirmininkas K. Venclauskis ịejo ị St. Seimo Seniūnų sueigą, i ją pa-

${ }^{103}$ Pakalka, J. Min. veik., p. 83.

${ }^{104}$ Ten pat.

${ }^{105}$ SSD. 1 p-dis, 192005 15, p. 5, 7; 2 p-dis, 192005 17, p. 7.

${ }^{106}$ SSD. 2 p-dis, 192005 17, p. 7.

${ }^{107}$ St. Seimo darbuotè. Socialdemokratas. 192006 24, Nr. 8, p. 2. 
gal 3-iame posėdyje priimtą St. Seimo statutą i̇ejo St. Seimo prezidiumas ir frakcijų atstovai ${ }^{108} .1921 \mathrm{~m}$. kurị laiką ị Seniūnų sueigą vietoj K. Venclauskio ịejo S. Digrys ${ }^{109}$. Kadangi ị St. Seimą išrinktų socialdemokratų darbo apibūdinimas ir analizė nèra šio straipsnio objektas, tai tuo ir būtų galima baigti Lietuvos socialdemokratų dalyvavimo St. Seimo rinkimuose ir jų rezultatų aptarimą.

\section{Išvados}

1. Lietuvių socialdemokratai (LSDP) nuo pat politinès veiklos pradžios ir pirmosios politinès programos prièmimo pasisakè už radikaliai demokratinę būsimos Lietuvos Respublikos valdymo formą, kur svarbiausia valdžios institucija būtų demokratiškai išrinktas parlamentas. Nuo XX a. pradžios LSDP dokumentuose ir partijos ideologų tekstuose buvo pasisakoma už tai, kad būsimos Lietuvos Respublikos politinès santvarkos pagrindus nustatytų St. Seimas. XX a. antro dešimtmečio pabaigoje dèl įvairių veiksnių ir aplinkybių susidarius galimybei (at)kurti Lietuvos valstybingumą socialdemokratijos ideologinei tradicijai likę ištikimi socialdemokratai nuolat pasisakẻ už tai, kad kiek galima greičiau būtų organizuoti St. Seimo rinkimai.

2. Socialdemokratų dalyvavimo St. Seimo rinkimuose aplinkybès buvo labai sudètingos: dar tik pradedanti atsikurti kaip organizacija, tuo metu itin negausi partija, veikianti valstietiškoje, nedaug darbininkijos turinčioje šalyje, 1919 m. rudenị - $1920 \mathrm{~m}$. pavasarị susidūrè su valdžios vykdomais varžymais (uždarytas laikraštis, neleista sušaukti partijos konferencijos, pasitaikẻ trumpalaikių žymių partijos veikejjų areštų etc.). Be to, socialdemokratai sulaukè komunistų, kurie veikè pogrindyje ir buvo gana populiarūs, itin aršaus idejjinio puolimo. Komunistai didelę agitaciją prieš socialdemokratus vykdè tarp

${ }^{108}$ SSD. 3 p-dis, 192005 18, p. 12; ten pat, 192005 22, p. 37.

${ }^{109}$ Mitrulevičius, G. Digrys Stasys, p. 122. 
pastarųjų socialine atrama turinčių būti darbininkų. Dèl darbininkų paramos socialdemokratams teko konkuruoti ir su krikščioniška LDF, gerokai stipresne kaip organizacija.

3. Nors socialdemokratams rinkimų i St. Seimą kampanijos aplinkybès ir ypatybès buvo palyginti nepalankios, jie keturiose iš šešių rinkimų apygardų sugebejjo iškelti savo partijos kandidatų sąrašus, kuriuose šalia iki tol nežinomų darbininkų, amatininkų ir tarnautojų buvo ir žinomų politikos bei visuomenės veikèjų, ir iki tol jau žinomų, o ateityje garsiais mokslininkais tapsiančių inteligentų, ir būsimų žymių Lietuvos ekonominio gyvenimo veikèjų, ir tuo metu jau žinomų, ateityje dar žymesniais tapsiančių teisininkų, ir vienas ateityje garsus Lietuvos diplomatas.

4. Atsižvelgiant ị labai sudètingą partijos organizacinę būklę, ne tik valdžios daromus varžymus, bet ir aršų komunistų puolimą, taip pat ị tokias objektyvias aplinkybes kaip agrarinis krašto pobūdis, nedidelis darbininkijos skaičius, galima daryti išvadą, kad LSDP St. Seimo rinkimuose pasirode palyginti sèkmingai - gavo beveik 13 proc. rinkejjų balsų ir 13 mandatų St. Seime. Socialdemokratai gana gerai pasirode Šiaulių, Biržų apskrityse (pirmos vietos tarp visų sąrašų), Rokiškio apskrityje (antra vieta tarp visų sąrašų), Kèdainių, Ukmergès, Vilkaviškio apskrityse (trečiosios vietos). Pagal rinkèjų balsų už partijos sąrašus skaičių, žvelgiant ì rinkimų rezultatus atskiruose miestuose, matyti, kad LSDP gana sẻkmingai pasirodė Kauno, Šiaulių ir Panevėžio miestuose.

5. Nors socialdemokratai itin kritiškai vertino St. Seimo rinkimų kampanijos aplinkybes bei ypatybes ir tvirtino, kad „Seimo rinkimai buvo sudaryti ir pravesti mūsų priešų ir aiškiai darbo žmonių nenaudai“, tačiau vis dèlto patị St. Seimo rinkimų faktą jie laikè naudingu darbininkų judejjimui, jo perspektyvoms ir tvirtino, kad su būsimu St. Seimo darbu Lietuvos darbininkai gaus „patogesnes sąlygas pasiruošti kovai su savo priešais, sustiprinti savo pajėgas ir eiti kovon atvirai didelèmis ir tvarkingomis miniomis“. 
6. Apibendrintai apibūdinant ì St. Seimą išrinktus socialdemokratus ir jų frakciją, galima teigti, kad tai buvo labiausiai išsilavinusi St. Seimo frakcija, turejjusi ryškių, jau iki tol savo veikla nacionalinio išsivadavimo judejjime (ypač per $1905 \mathrm{~m}$. revoliucinius ịvykius) pagarsẻjusių, o ateityje ryškų vaidmenį tarpukario Lietuvos politiniame, ekonominiame bei socialiniame gyvenime suvaidinusių asmenybių, patyrusių ir užgrūdintų kovotojų už nepriklausomą demokratinę Lietuvą ir socialdemokratijos (socializmo) idealus. Ne vienas jų praeityje dèl to buvo trumpesni ar ilgesnị laiką suimtas ir kalintas carinès Rusijos kalejjimuose.

\title{
LITHUANIAN SOCIALDEMOCRATS AND CONSTITUTIVE SEIM: PARTICIPATION IN ELECTION, RESULTS, FACTION
}

\author{
Gintaras Mitrulevičius
}

\section{Summary}

Keywords: Constitutive Seim; Elections of the Seim (1920); Social demokrats; LSDP; The faction of social democrats.

Lithuanian socialdemocrats spoke up for radically democratic form of governance of future Republic of Lithuania from the very beginning of their work and adaption of their first political program. From the beginning of the XX cent. Socialdemocrats spoke up for the institution of basics of political system of the Republic of Lithuania by the Constitutive Seim. At the of the end second decade of the XX cent. Social democrats, who were loyal to the social democratic ideological tradition, kept speaking up for the organisation of elections to the Constitutive Seim as soon as it was possible. In the article are discussed different aspects of the relation between Lithuanian socialdemocrats and Constitutive Seim, with reference to different sources and historiography. The aspects are such as: circumstances and features of the participation in elections, lists of candidates, results of election, its evaluation, objectives and aims of the faction of social democrats in the Seim. After analysing these aspects it was come up with following conclusions:

1. The situation of the participation of social democrats in the election to the 
Constitutive Seim was rathen complicated: in 1919-1920 the social democratic party confronted with restriction from the side of government and savage ideological attack from the side of communists, who worked underground.

2. Though circumstances of election to the Constitutive Seim were not beneficial to social democrats, they managed to nominate the lists of the party candidates in four from six constituencies. In the lists of candidates there were not only unknown workmen, tradespeople or office workers, but also known political and society people;

3. Considering especially complicated organisational state of the party, restriction of the government, savage attack of communists and other objective circumstances, election to the Constitutive Seim was rather successful to LSDP, as they got 13 percent of electorate votes and 13 mandates in Constitutive Seim.

4. Though social democrats judged the campaign of election to the Constitutive Seim especially critically, they considered the fact of election itself as very useful to the movement of workers and claimed that they will get better conditions to prepare for the fight with enemies and strenghten their force.

5. The faction of social democrats was the most educated faction in the Constitutive Seim. It had several personalities who later took an active part in politicall, economical and social life of Lithuania, and experienced and tempered fighters for independent Lithuania and ideals of social democrasy.

Iteikta $2019 \mathrm{~m}$. kovo $15 \mathrm{~d}$. 